\title{
Cerulean warbler relative abundance and frequency of occurrence relative to large-scale edge
}

\author{
Scott B. Bosworth \\ West Virginia University
}

Follow this and additional works at: https://researchrepository.wvu.edu/etd

\section{Recommended Citation}

Bosworth, Scott B., "Cerulean warbler relative abundance and frequency of occurrence relative to largescale edge" (2003). Graduate Theses, Dissertations, and Problem Reports. 1820.

https://researchrepository.wvu.edu/etd/1820

This Thesis is protected by copyright and/or related rights. It has been brought to you by the The Research Repository @ WVU with permission from the rights-holder(s). You are free to use this Thesis in any way that is permitted by the copyright and related rights legislation that applies to your use. For other uses you must obtain permission from the rights-holder(s) directly, unless additional rights are indicated by a Creative Commons license in the record and/ or on the work itself. This Thesis has been accepted for inclusion in WVU Graduate Theses, Dissertations, and Problem Reports collection by an authorized administrator of The Research Repository @ WVU. For more information, please contact researchrepository@mail.wvu.edu. 
Cerulean Warbler Relative Abundance and Frequency of Occurrence Relative to Large-scale Edge

Scott B. Bosworth

Thesis submitted to the Davis College of Agriculture, Forestry, and Consumer Sciences at West Virginia University in partial fulfillment of the requirements

for the degree of

Master of Science

in

Wildlife and Fisheries Resources

Petra Bohall Wood, Ph. D., Chair

Randy Dettmers, Ph. D.

James T. Anderson, Ph. D.

Division of Forestry

Morgantown, West Virginia 2003

Keywords: Cerulean Warbler, Abundance, Occurrence, Edge Effects, Fragmentation, Mountaintop Mining/Valley Fill 


\begin{abstract}
Cerulean Warbler Relative Abundance and Frequency of Occurrence Relative to Large-scale Edge
\end{abstract}

Scott B. Bosworth

Cerulean Warblers (Dendroica cerulea) were studied in southwestern West Virginia where the coal mining technique of mountaintop mining/valley fill (MTMVF) continues to perforate large contiguous tracts of deciduous forest. My study objectives were to (1) quantify abundance and probability of occurrence of Cerulean Warblers relative to distance from largescale edge (defined as reclaimed MTMVF sites) and (2) relate habitat structure and landscape characteristics to the species' probability of occurrence. Cerulean Warbler abundance increased significantly $(P<0.10)$ with distance from reclaimed mine edge. However, percent occurrence relative to distance from mine edge was not significant, suggesting a degree of tolerance to the large-scale edge created by MTMVF. Abundance was significantly greater on ridges than bottomlands. Percent occurrence did not differ among the three slope positions but followed a trend similar to abundance. Consequently, disturbances such as MTMVF in which ridges are removed may have a greater impact on populations compared to other sources of fragmentation where ridges are not disturbed. Other habitat structure analyses suggest good indicators of Cerulean Warbler presence are the more productive sites on northwest to east facing slopes and low sapling density. Similarly, Cerulean Warbler abundance was positively associated with more productive sites and snag density. Important landscape characteristics positively associated with abundance were large blocks of mature deciduous forest and low edge density. Mountaintop mining/valley fill alters the spatial configuration of forested habitats in southwestern West Virginia, thus creating less suitable habitat and edge effects that negatively affect Cerulean Warbler abundance, occurrence, and distribution in the reclaimed mine landscape. 


\section{ACKNOWLEDGEMENTS}

Many individuals and funding sources contributed to the successful completion of this research. First and foremost I would like to thank Petra Bohall Wood for giving me a chance to pursue a lifetime goal of conducting avian research and obtaining a Master's of Science degree in Wildlife and Fisheries Management. Her guidance, understanding, and knowledge provided me with confidence and the ability to overcome many obstacles (or fears such as presentations) in the field of Wildlife and Fisheries Management. I also thank James T. Anderson, Randy Dettmers, and Cathy A. Weakland (Katie) for their technical support and advice for my research and on this manuscript. Thank you Katie for taking an extra

step to ensure my understanding of Arcview and SAS procedures. A special thanks goes to George Seidel for his countless hours of help with statistical analyses and having the patience to explain statistical procedures to me over and over again. I would also like to thank my field technicians Amanda Carroll, Tim Dellinger, Kevin Boyle, and Tony Bosworth (Dad) for working extremely long hours under adverse conditions. Especially Amanda for the encouragement and knowledge she brought to the field from start to finish, which played a vital role in the completion of the field work. Last but definitely not least and of course most importantly, I would like to thank my wife Michele for inspiring me to pursue my dreams, overcome adversity, and being there for me every step of the way. I love you always.

Funding was provided through the U.S. Fish and Wildlife Service, Quick Response Program. I thank Arch Coal, Cannelton, and Amherst Corporations for granting me access to their properties. Ark Land Company provided field housing. I also thank the West Virginia Cooperative Fish and Wildlife Research Unit, USGS, BRD for providing me with field equipment, research travel money, free food (on special occasions), and comic relief (thanks Becky Nestor) throughout my stay at West Virginia University. 


\section{TABLE OF CONTENTS}

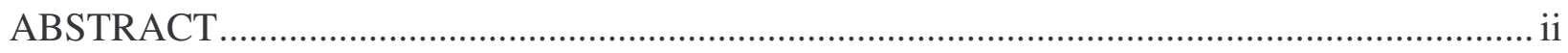

ACKNOWLEDGEMENTS .............................................................................................

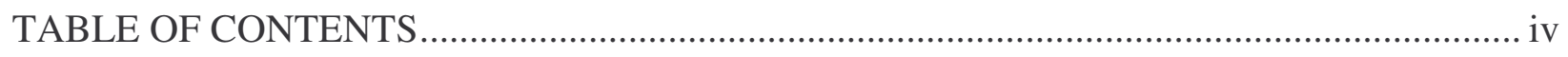

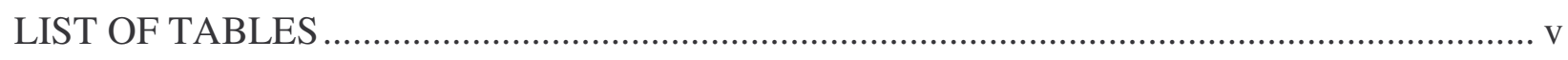

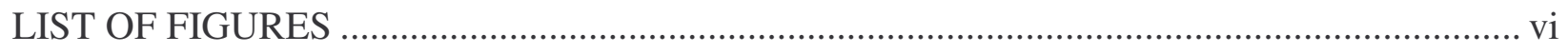

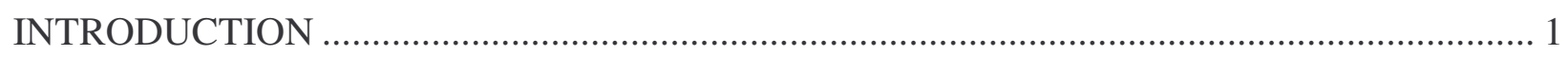

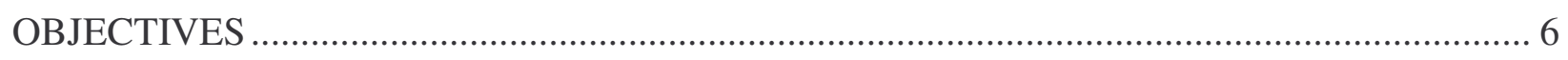

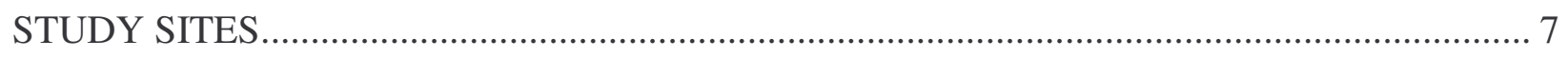

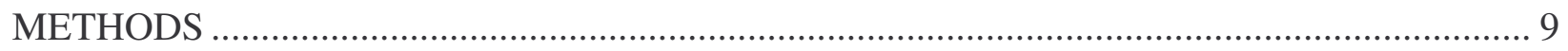

Cerulean warbler abundance and probability of occurrence ........................................... 9

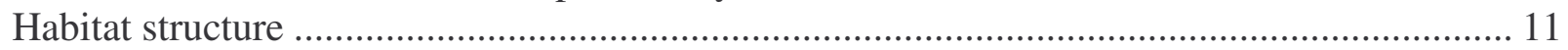

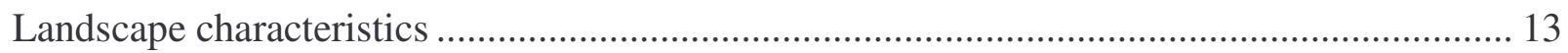

Statistical Analyses ..................................................................................................... 14

Presencelabsence relative to microhabitat and disturbance variables ............................... 14

Abundance and percent occurrence relative to distance ................................................... 15

Abundance and percent occurrence relative to slope position ............................................ 15

Abundance and percent occurrence relative to landscape metrics..................................... 16

Microhabitat and landscape models .......................................................................... 16

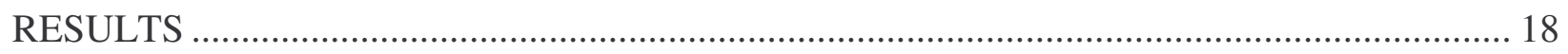

Abundance and percent occurrence ...................................................................... 18

Microhabitat and landscape characteristics ........................................................... 18

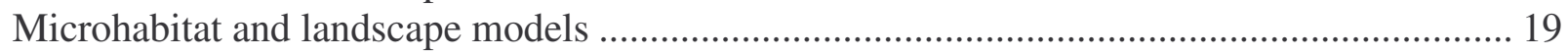

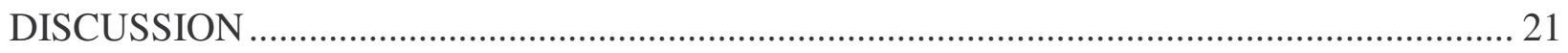

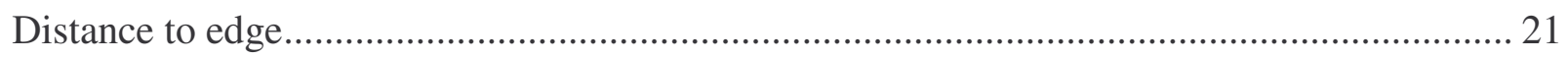

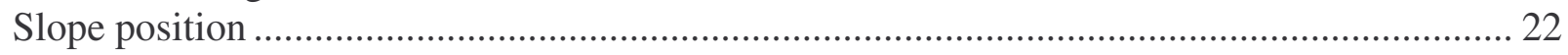

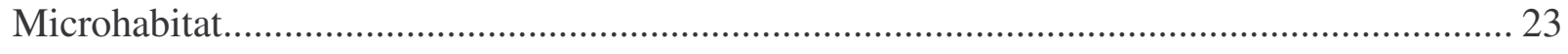

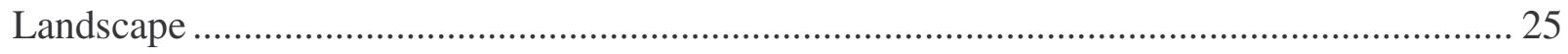

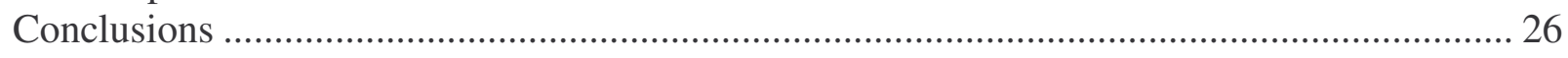

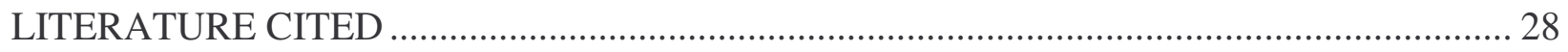




\section{LIST OF TABLES}

Table 1. Abbreviations and descriptions of microhabitat variables measured at vegetation plots in southwestern West Virginia, 2002 ............................................................................ 36

Table 2. Abbreviations and descriptions of disturbance types measured within $100 \mathrm{~m}$ radius of each point count station in southwestern West Virginia, 2002.

Table 3. Descriptions of landscape variables measured within $3 \mathrm{~km}$ radius circular plot from each cluster centroid in southwestern West Virginia, 2002.

Table 4. Sampling effort, percentage of points with Cerulean Warblers (CERW), and abundance at each slope position in southwestern West Virginia, 2002 ........................................ 38

Table 5. Cerulean Warbler (CERW) occurrence relative to microhabitat variables measured at vegetation plots in southwestern West Virginia, 2002 ................................................. 39

Table 6. Cerulean Warbler (CERW) occurrence relative to type and amount of disturbance within $100 \mathrm{~m}$ radius from each point count station in southwestern West Virginia, 2002.... 40

Table 7. Cerulean Warbler (CERW) mean abundance relative to landscape variables calculated within $3 \mathrm{~km}$ radius from each cluster centroid in southwestern West Virginia, 2002 ......... 41

Table 8. Best 5 models relating Cerulean Warbler presence/absence relative to microhabitat

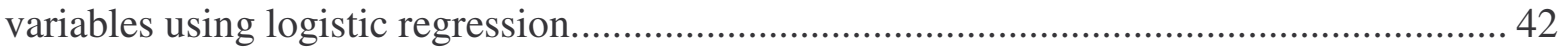

Table 9. Best 5 models relating Cerulean Warbler abundance relative to microhabitat variables using poisson regression.................................................................................. 42

Table 10. Best 5 models relating Cerulean Warbler mean abundance relative to landscape variables using linear regression. 


\section{LIST OF FIGURES}

Figure 1. Mountaintop mining/valley fill study sites in southwestern West Virginia, 2002...... 43

Figure 2. Point count stations in forested habitat at mountaintop mining/valley fill site Hobet 21

in southwestern West Virginia, 2002 ........................................................................... 44

Figure 3. Point count stations in forested habitat at mountaintop mining/valley fill site Daltex in

southwestern West Virginia, 2002. 45

Figure 4. Point count stations in forested habitat at mountaintop mining/valley fill site Cannelton in southwestern West Virginia, 2002. 46

Figure 5. Point count station location and transect layout relative to distance from reclaimed mountaintop mining/valley fill (MTMVF) sites in southwestern West Virginia, 2002........ 47

Figure 6. Linear disturbances within $100 \mathrm{~m}$ radius of each point count station in southwestern West Virginia, 2002. Before digitizing (a) and after digitizing (b)................................ 48

Figure 7. Aerial photograph digitized into 3 land use/land cover categories within a $3 \mathrm{~km}$ buffer from a cluster centroid in a mountaintop mining/valley landscape in southwestern West Virginia, 2002

Figure 8. Cerulean Warbler (CERW) abundance relative to all distances $(n=122)$ from reclaimed mine edge in southwestern West Virginia during May - July 2002. Distance categories were created and mean abundances were calculated to simplify the figure.

Figure 9. Cerulean Warbler (CERW) percent occurrence (percent of points with CERW present) relative to distance categories in southwestern West Virginia, 2002.

Figure 10. Cerulean Warbler (CERW) mean abundance relative to slope position in southwestern West Virginia during May - July 2002. Like letters indicate no significant difference.

Figure 11. Cerulean Warbler (CERW) mean abundance relative to percent forest cover $\left(R^{2}=0.52, F=4.52, P=0.05\right)$ in southwestern West Virginia during May - July 2002. Forest cover is the combination of deciduous cover and mixed conifer-deciduous.

Figure 12. Cerulean Warbler (CERW) mean abundance relative to percent deciduous forest cover $\left(R^{2}=0.51, F=4.19, P=0.06\right)$ in southwestern West Virginia during May - July 2002. . 52

Figure 13. Cerulean Warbler (CERW) mean abundance relative to forest core area $\left(R^{2}=0.52\right.$, $F=4.59, P=0.05)$ in southwestern West Virginia during May - July 2002.

Figure 14. Aspects of point count stations where Cerulean Warblers were present $(n=69)$ in southwestern West Virginia during May - July 2002. Seventy percent of the point count stations are above the dashed line ranging from northwest to east facing slopes. 


\section{INTRODUCTION}

Many Neotropical migrant bird populations have experienced declines across much of their breeding range. The loss of wintering, breeding, and migration stopover habitats may be contributing factors (Robinson 1993). Cerulean Warblers (Dendroica cerulea Wilson) are one of many Neotropical migrants considered to be a species of conservation concern (Robbins et al. 1992).

Cerulean Warblers are small canopy insectivores that breed throughout much of the eastern United States, in mature, often large tracts of deciduous forest with horizontal heterogeneity of the canopy (Hamel 2000a). Cerulean Warbler breeding habitat across their range has been further identified with a relatively open understory in mature forests of wet bottomlands, uplands, and mountains ranging from $<30 \mathrm{~m}$ to $>1000 \mathrm{~m}$ elevation (Hamel 2000a). More specifically, in West Virginia they have been identified at elevations from $171 \mathrm{~m}$ to 1067 $\mathrm{m}$ in predominately dry slope/ridgetop sites (65\% of observations) and the remaining $35 \%$ almost equally divided between moist slope/cove and bottomland/riparian habitat sites (Rosenberg et al. 2000). The large range of elevations throughout the breeding range of the Cerulean Warbler encompasses a great diversity of flora, resulting in no apparent preferences of tree species or groups for nesting and foraging (Hamel 2000a). In West Virginia, however, Cerulean Warblers occupied forest sites dominated by oaks (Quercus spp.), maples (Acer spp.), hickories (Carya spp.), and tulip trees (Liriodendron tulipifera) (Rosenberg et al. 2000).

Although historically described as one of the most abundant breeding warblers in the Ohio and Mississippi River valleys, Cerulean Warbler relative abundance has declined since the early 1900s (Hamel 2000a). Breeding Bird Survey (BBS) data indicate that Cerulean Warbler populations have declined significantly (4.2\% per year) since 1966 throughout their range 
(Rosenberg et al. 2000, Sauer et al. 2001), which has led to a petition for listing as threatened under the Endangered Species Act (ESA).

Robbins et al. (1992) identified 6 breeding constraints possibly affecting Cerulean Warbler populations. First, loss of mature deciduous forest to urbanization and/or conversion to agricultural land has made potential breeding habitat uninhabitable for the warbler. A second constraint is fragmentation and increasing isolation of remaining mature deciduous forest relative to the proportion of the landscape that is forested. Fragmented landscapes may serve as population sinks for breeding birds (Donovan et al. 1995, Robinson et al. 1995). Third, timber harvest practices such as shorter rotation periods and even-aged management have allowed less deciduous forest to mature, which potentially limits habitat for the warbler. Fourth, loss of key tree species from insects and disease may be another breeding constraint the warbler faces. Tree species such as oak have been lost from oak wilt disease and gypsy moths (Lymantria dispar), sycamores (Platanus occidentalis) from a fungus, elms (Ulmus spp.) from Dutch elm disease, and American chestnuts (Castanea dentata) from chestnut blight (Cryphonectria parasitica). Of these diseases and insects introduced by humans, chestnut blight and gypsy moths have the most impact or potential impact on structure and composition of the central hardwood forest (Hicks 1998). Fifth, environmental degradation caused by acid rain and stream pollution, particularly within major breeding areas may have negative impacts on Cerulean Warbler populations. Finally, nest parasitism by the Brown-headed Cowbird, which can be directly related to the extent of fragmentation (Gates and Evans 1998) also may have negative impacts on Cerulean Warbler populations.

The results of the Cerulean Warbler Atlas Project (CEWAP) indicate that West Virginia and 3 other states (TN, NY, IL) in the Cerulean Warbler breeding range contain the largest 
numbers of birds (Rosenberg et al. 2000). However, areas near the periphery of the species' range $(\mathrm{NY}, \mathrm{IL})$ were more completely sampled than areas near the center of the range (WV, TN, PA, KY) (Rosenberg et al. 2000). In West Virginia the greatest concentration of Cerulean Warblers appears to be distributed throughout the Ohio Hills and Cumberland Plateau physiographic provinces, with Ridge and Valley containing smaller scattered populations (Rosenberg et al. 2000).

Previous research has shown that Cerulean Warbler populations are expanding their range in northeastern North America, occupying landscapes formerly used for agricultural purposes (Oliarnyk 1996). This suggests that the species is opportunistic and will occupy second-growth as well as mature forest (Hamel 2000a). West Virginia is 79\% forested (Smith et al. 2001), predominately second-growth, and believed to be a stronghold for breeding populations. In particular, southwestern West Virginia may represent a source population for the eastern United States (Rosenberg and Wells 2000). Donovan et al. (1995) and Robinson et al. (1995) suggested that extensively forested landscapes may serve as population sources for breeding birds. However, loss of forested habitat resulting from silvicultural treatments and mining practices has begun to impact the large second-growth, contiguous tracts of deciduous forest in West Virginia, possibly decreasing habitat suitability for breeding populations of the Cerulean Warbler.

Certain forest management activities may be compatible with the conservation of Cerulean Warblers. Hamel (2000b) suggested that management for quality sawtimber products, involving long rotations with intermediate treatments may produce a varied 3-dimensional stand with an extensive network of canopy gaps, resulting in suitable habitat. In the early $20^{\text {th }}$ century, West Virginia forests were predominately clearcut, currently resulting in a rather homogenous 
forest structure. Creation of vertical and horizontal forest structure through management for sawtimber products may create suitable breeding habitat locally for Cerulean Warblers. In contrast, short rotations and even-aged management result in the loss of mature forests and the creation of a homogenous canopy structure, which may be a breeding season constraint (Robbins et al. 1992).

Effects of various mining practices on Cerulean Warbler populations are less understood, particularly mountaintop mining/valley fill (MTMVF) techniques and its creation of large-scale edge. Mountaintop mining/valley fill is a coal mining technique that began in the 1960s and is used in West Virginia, Virginia, Tennessee, Kentucky, and Pennsylvania (United States Environmental Protection Agency 2000). More specifically, in West Virginia MTMVF is currently practiced throughout the southwestern part of the state, primarily in the upper part of the Kanawha and Allegheny coal formations (Fedorko and Blake 1998). Use of this method has increased significantly in response to the greater demand for low sulfur coal needed to meet standards set by the Clean Air Act (Fedorko and Blake 1998). In general this mining technique requires the removal and disposal of overburden to expose the coal seams for the extraction of coal. Mountaintop/valley fill mining creates a disturbance where most ridge components are removed from the landscape. The impacted areas are often large, up to 2000+ ha in size, converting predominately forested landscapes to early successional habitats with remnant forest patches. Under the Surface Mining Control and Reclamation Act of 1977, the impacted mining areas must be reclaimed as closely as possible to pre-mining conditions, unless a variance is granted (Musgrave et al. 1998).

Although habitat fragmentation and edge resulting from MTMVF may appear to be similar to the effects of common agricultural and silvicultural practices, they differ greatly. 
Mountaintop mining/valley fill alters the geology by inverting parent material and destroying soil horizons, which in turn affects the hydrology, soils, and most forms of biota, initiating primary succession. In contrast, agricultural and silvicultural practices initiate secondary succession without the prolonged stages of soil building (Nebel and Wright 1998). Barbour et al. (1999) suggest primary succession can require up to 10 fold more time to complete than secondary succession.

Based on Leopold's law of interspersion (Leopold 1933), many biologists believe that increasing the amount of edge habitat results in higher population densities of various wildlife species (Guthery and Bingham 1992). Other wildlife biologists, however, have challenged the law of interspersion, stating that while edge generally may increase abundance and diversity of game species, other species are affected negatively (Guthery and Bingham 1992). Avian population declines in eastern North America, as a consequence of fragmented landscapes has drawn recent interest in edge effects (Askins et al. 1990, Robbins et al. 1992). However, there is little consensus among researchers on what an edge is and standard criteria are lacking in the classification of edge (Paton 1994, Murcia 1995). Paton (1994) in a review of effect of edge on avian nest success, suggested that only openings in the forest canopy with a diameter 3 times or more the height of the adjacent trees should be considered an edge, while smaller openings should be excluded. He based these criteria on a study conducted by Minckler and Woerheide (1965), who found that environmental conditions in an opening that is 2 to 3 times the height of the surrounding trees are almost equal to conditions in much larger openings.

Changes in abiotic and biotic conditions resulting from edge may affect organisms in a forest fragment (Saunders et al. 1991). Abiotic, direct biological, and indirect biological are 3 different types of edge effects that may occur on fragmented forests (Murcia 1995). Abiotic 
effects are changes in environmental conditions resulting from the interaction between 2 structurally dissimilar ecosystems (Murcia 1995). Direct biological effects are changes in abundance and distribution of species in relation to edge and result from physical conditions near edge and physiological tolerances of species (Murcia 1995). Edge may increase predation, brood parasitism, and competition among species (Faaborg et al. 1995), which are examples of indirect biological effects (Murcia 1995).

While the effect of edges on avian nesting success has been well defined in agricultural areas, fewer studies have described the effects of fragmentation and edge in extensively forested landscapes (Manolis et al. 2000). Mature deciduous forest remains the predominate habitat in southwestern West Virginia where MTMVF is taking place. However, loss of mature deciduous forest has made potential breeding habitat uninhabitable for the warbler (Robbins et al. 1992). Continued MTMVF and associated development may increase the rate of the fragmentation process and begin to isolate remaining forest tracts. To conserve forest interior and area sensitive species such as the Cerulean Warbler in extensively forested regions, it is important to understand the potential impacts of fragmentation and edges created by MTMVF. With increasing forest fragmentation and the lack of knowledge of landscape characteristics of the Cerulean Warbler and its distribution in relation to habitat fragmentation or edge, the fate of the Cerulean Warbler is unknown.

\section{OBJECTIVES}

The study objectives were (1) to quantify relative abundance and probability of occurrence of Cerulean Warblers relative to distance from large-scale edge (defined as reclaimed MTMVF sites) and (2) relate habitat structure and landscape characteristics to the species' probability of occurrence. 


\section{STUDY SITES}

The study sites were located in the Ohio Hills and Cumberland Transition physiographic provinces (Robbins et al. 1986) in southwestern West Virginia on and adjacent to 3 MTMVF sites (Figure 1). The Hobet 21 mine (2431 ha) was located in Boone County within the Little Coal River and Mud River watersheds. The Daltex mine (1819 ha) was located in Logan County within the Spruce Fork watershed. The Cannelton mine (2180 ha) was located along the border of Kanawha and Fayette Counties within the Twentymile Creek watershed.

Soils in the unmined forested areas on and adjacent to my study sites primarily consist of moderately deep to very deep Inceptisols or Ultisols. Soils in forested areas on and adjacent to Hobet 21 are in the Berks-Shelocta soil association characterized as very steep and very stony (United States Department of Agriculture Soil Conservation Service 1994). Berks soils are located on ridgetops and side slopes and described as moderately deep. Shelocta soils occur on foot slopes, side slopes, and coves and are described as very deep (United States Department of Agriculture Soil Conservation Service 1994). Soils in forested areas on and adjacent to Cannelton are in the Clymer-Dekalb-Gilpin association characterized as strongly sloping to very steep and well-drained acid soils (United States Department of Agriculture Soil Conservation Service 1981). Clymer soils occur on uplands and are described as deep and strongly sloping to very steep. Dekalb soils are found on rough uplands and are described as moderately deep and moderately steep to very steep. Gilpin soils are occur on uplands and are described as moderately deep and strongly sloping to very steep (United States Department of Agriculture Soil Conservation Service 1981). Recent soils data for Daltex or Logan County is currently not available, but appears similar to the Hobet 21 sites. 
Point count stations were placed in 3 fragmented forest patches (103 ha, 290 ha, and 420 ha in size) and in adjacent relatively intact forest that are representative of the forested habitat in southwestern West Virginia (Figures 2, 3, and 4). Elevations ranged from 253-566 m. Intact and fragmented forests are second-growth, approximately 60-80 years of age, and comprised of predominately hardwood species. The primary forest type was mixed mesophytic forest (Strausbaugh and Core 1977), which included primarily oaks, hickories, tulip poplar, American beech (Fagus grandifolia), red maple (A. rubrum), sugar maple (A. saccharum), and white ash (Fraxinus americana) with small patches of eastern hemlock (Tsuga canadensis) scattered throughout, particularly along stream drainages.

The extensive forest surrounding the reclaimed mines has periodically undergone many anthropogenic changes. These anthropogenic changes vary from induced edge to natural changes, otherwise known as inherent edge (Yahner 1988), resulting in large and small canopy openings. Disturbances included residential areas, networks of road highways, few pasture fields, abandoned strip mine high-walls, deep mines, timber harvests, understory forest fires, jeep and/or all-terrain vehicle trails, powerline corridors, firewood cutting, and natural canopy gaps. Vegetation associated with these disturbances varied with disturbance type. Bare ground, gravel and/or pavement bordered with primarily Rubus species were indicative of the roads and trails. Vegetation associated with abandoned strip mines, deep mines, and timber harvests included primarily early succession forest (e.g. shrub/pole) with few mature deciduous trees depending on harvest type. Powerline corridors were typically maintained grasses interspersed with scattered shrubs and forbs.

The forest/reclaimed mine interface on my sampling sites was an abrupt transition from reclaimed grassland to forest. This edge included very little regeneration and did not have a 
gradient of successional stages indicative of a more natural, feathered edge. The edge shape was convoluted, which results in greater edge to area ratio as the forest shape diverges from circular (Hunter 1990).

The reclaimed mine landscape mostly consisted of grasses with scattered shrubs and a few patches of pole forests. Primary vegetative species in the grassland areas (5-19 years of age) included tall fescue (Festuca arundinacea), sericea (Lespedesa cuneata), autumn olive (Elaeagnus umbellata), multiflora rose (Rosa umbellate) and legumes such as birdsfoot trefoil (Lotus corniculatus) and purple vetch (Vicia americana) (Balcerzak and Wood 2003). Older reclaimed mine areas (13-27 years of age) primarily consisted of shrub and pole sized vegetative species such as black locust (Robinia pseudoacacia), European black alder (Alnus glutinosa), Rubus species, red pine (Pinus resinosa), scotch pine (Pinus sylvestris) and pitch pine (Pinus rigida) (Balcerzak and Wood 2003).

\section{METHODS}

\section{Cerulean warbler abundance and probability of occurrence}

I established 122 point count stations to quantify relative abundance and probability of occurrence of Cerulean Warblers relative to distance from large-scale edge. I spaced the point count stations $\geq 250 \mathrm{~m}$ apart and extended them outward from the reclaimed mine edge into adjacent forested habitat. I located approximately two thirds of the points (86) along transects at

distances ranging from $40 \mathrm{~m}$ to $1140 \mathrm{~m}$ (Figures 2, 3, 4, and 5). The starting point of one third of these transects was at $40 \mathrm{~m}$ from the mine edge, one third were at $90 \mathrm{~m}$ from the mine edge, and one third were at $140 \mathrm{~m}$ from the mine edge (Figure 5). I placed the remaining 36 points at distances ranging from $1440 \mathrm{~m}$ to $3070 \mathrm{~m}$ for landscape habitat analyses. I arranged all points in clusters (4-7 points per cluster) to minimize travel time between points on the same sampling 
day. I created 7 clusters at each mine, each $\geq 1 \mathrm{~km}$ apart for landscape habitat analyses (Figures 2, 3, and 4).

I avoided placing points near canopy gaps with a diameter 3 times or more the height of the adjacent trees (Paton 1994) to reduce multiple edge effects at a point because my primary interest was the reclaimed mine/forest edge effect. To avoid edges from canopy gaps, I used Arcview ${ }^{\circledR} 3.2$ (Environmental Systems Research Institute 1996) to view 1997 aerial photos to locate edge. To maximize edge detection, I used ground-truthing throughout the sampling period to ensure canopy gaps with a diameter of 3 times or more the height of the adjacent trees were not closer to the point count station than the distance to reclaimed mine edge.

Point count stations also were located at various slope positions including ridgetops, midslopes, and bottomlands. I determined slope position based on vegetative communities and/or geologic formations. I defined ridgetops as areas that tended to be near mountain tops or topographic high points with rocky outcrops, little leaf litter, large amounts of common greenbrier (Smilax rotundifolia), lowbush blueberry (Vaccinium angustifolium), and oak trees. I defined mid-slopes as areas between ridgetops and bottomlands that tended to have tree species such as tulip poplar, hickories, and maples, and large amounts of leaf litter. I defined bottomlands as areas often near low gradient streams that tended to contain tree species such as black birch (Betula lenta), eastern sycamore (Platanus occidentalis), and eastern hemlock.

I used standard point count survey methods (Ralph et al. 1993) to count all individuals seen or heard during 10 minute counts from 0600 to 1000. Although Ralph et al. (1993) suggested using $50 \mathrm{~m}$ fixed radius plots, I placed all individuals detected into 2 distance categories (0-50 m radius and $>50-100 \mathrm{~m}$ radius). Before surveys began I conducted multiple field tests in the study area and did not detect any Cerulean Warblers beyond $100 \mathrm{~m}$, therefore I 
did not survey beyond the $100 \mathrm{~m}$ radius. I included the larger category $(>50-100 \mathrm{~m})$ to increase the probability of detecting Cerulean Warblers during counts. Jones et al. (2000) found that a 50-m fixed radius consistently overestimated actual Cerulean Warbler densities while the 100-m fixed radius underestimated densities, although both methods were effective in providing relative indices to abundance. Further, they found a stronger relationship to actual density with 100-m radius plots. No surveys were conducted during rainy or windy weather. Each point was surveyed 2 times during the breeding season, beginning May 15, 2002 and ending June 30, 2002 by 1 of 3 observers trained in bird identification and distance estimation (Verner and Milne 1989). Prior to beginning surveys, observers practiced bird identification and distance estimation on study sites in various vegetative communities to maximize census precision (Bart and Schoultz 1984).

\section{Habitat structure}

I used a modified version of the BBIRD protocol (1997) to measure vegetation at each point count station (Martin et al. 1997). At each point count station, I measured vegetative structure and composition on two 0.04 ha circular vegetation plots, one centered at the point and the other at a distance of $35 \mathrm{~m}$ in a randomly selected direction. Aspect, percent slope, average upper canopy height, percent cover of vegetative layers, and stem densities were measured on each vegetation plot (Table 1). I used a compass to measure aspect and a clinometer to measure percent slope and average upper canopy height.

Vegetative layers, percent canopy cover, and percent ground cover were measured using the James and Shugart (1970) optical sight tube method at 20 sample points every $2.26 \mathrm{~m}$ along two perpendicular transects. Transects were $22.6 \mathrm{~m}$ long and intersected at the center of each 0.04 ha circular plot. The optical sight tube is a $5 \mathrm{~cm}$ PVC pipe with crosshairs at one end used 
to measure presence/absence of ground cover, canopy cover, and vegetative layers on the 20 sample points. Ground cover categories included green, bare ground/rock, moss, woody debris ( $\geq 4 \mathrm{~cm}$ in diameter), water, or leaf litter. Canopy cover was recorded for 6 height categories:

0.5-3 m, $>3-6 \mathrm{~m},>6-12 \mathrm{~m},>12-18 \mathrm{~m},>18-24 \mathrm{~m}$, and $>24 \mathrm{~m}$. Concurrently, covers of functional vegetative layers (shrub, midstory, lower canopy, and upper canopy) also were recorded. I defined the shrub layer as a layer consisting woody plants with multiple stems or small saplings that were generally less than $3 \mathrm{~m}$ in height. The midstory layer included small to medium size trees that did not reach the lower canopy. I defined the lower canopy the main canopy layer containing co-dominate tree species. The upper canopy layer consisted of the dominate trees extending beyond the lower canopy.

All tree species $\geq 8 \mathrm{~cm}$ diameter at breast height ( $\mathrm{dbh}$ ) within the 0.04 ha circular plots were counted, measured, and placed into 4 size categories: $8-23 \mathrm{~cm},>23-38 \mathrm{~cm},>38-53 \mathrm{~cm}$, and $>53 \mathrm{~cm}$. In a 0.008 ha $(5 \mathrm{~m}$ radius) circular plot centered on the vegetation plot, all stems $<8 \mathrm{~cm}$ diameter at $10 \mathrm{~cm}$ above ground and $>0.5 \mathrm{~m}$ tall were counted and placed into 2 size categories: $<3 \mathrm{~cm}$ and $\geq 3-7 \mathrm{~cm}$.

I identified all disturbances that created gaps in the canopy (Table 2) within $100 \mathrm{~m}$ of each point count station. For all canopy gaps, I estimated size of canopy opening $\left(\mathrm{m}^{2}\right)$ in the field and paced the distance $(\mathrm{m})$ from the point count station to the gap. I mapped the location of linear (e.g. roads and powerline corridors) and timber harvest disturbances in the field. I then digitized the boundary of each linear and timber harvest canopy disturbance mapped in the field on digital aerial photographs at a map scale of $\leq 1: 2000$ to quantify the area using Arcview ${ }^{\circledR}$ (Figure 6). 


\section{Landscape characteristics}

For landscape characteristics, I used Arcview ${ }^{\circledR}$ to create $3 \mathrm{~km}$ radius buffers around the centroid of each cluster of points on 1997 National Aerial Photography Program (NAPP) aerial photographs. Because some changes have occurred since photos were taken in 1997, I updated coverages to reflect changes found through ground-truthing. Within the $3 \mathrm{~km}$ buffers at a map scale of $\leq 1: 5000$, I digitized landscapes into 3 land use/land cover categories: deciduous forest, mixed coniferous-deciduous forest, and non-forest (grassland/barren, water, developed, road, riparian, and early-successional cover types) (Figure 7). Although Paton (1994) suggested that only openings in the forest canopy with a diameter 3 times or more the height of the adjacent trees should be considered an edge, I applied a more conservative approach when digitizing nonforested areas to minimize error associated with digitizing and data layering. I digitized all nonforested areas with a diameter $\geq 26 \mathrm{~m}$ because the mean canopy height across all of my vegetation plots was $26 \mathrm{~m}$. I then calculated percentages of each cover type within the $3 \mathrm{~km}$ radius landscapes.

Using Patch Analyst ${ }^{\odot}$ (McGarigal and Marks 1994, Elkie et al. 1999) extension in Arcview $^{\circledR}$, I used the 3 land covers to calculate fragmentation indices, including mean forest patch size (MPS), area weighted mean shape index (AWMSI), and Shannon's diversity index (SDI) (Table 3). To calculate total forest core area (TCA), mean size of forest core areas (MCA), core area density (CAD), and edge density (ED), I dissolved the 3 land covers into 2 categories, forest (deciduous plus mixed coniferous deciduous forests) and non-forest (Table 3), from which grids were created (cell size $=24$, rows $=250$, columns $=250$ ). Then by selecting PatchGrid and Grid Statistics in Arcview ${ }^{\circledR}$, I calculated values for the latter metrics. Edge effect studies on 
avian nest success suggest that edge effects occur within $50 \mathrm{~m}$ of an edge (Paton 1994), therefore I calculated forest core area by subtracting $50 \mathrm{~m}$ buffers from forest patches.

\section{Statistical Analyses}

All data summaries and analyses were performed using SAS ${ }^{\circledR}$ (SAS Institute 1991). Because a conservative approach is often justified when examining factors causing population declines (Askins et al. 1990, Caughley and Gunn 1995), particularly for a species of conservation concern, I used a conservative approach for all statistical analyses and considered differences significant at $\alpha=0.10$. When one-way analysis of variance (ANOVA) or covariance (ANCOVA) indicated significant differences, I used Waller-Duncan K-ratio $t$ tests to identify which means differed.

All microhabitat, landscape, and disturbance variables were tested for normality using the Shapiro-Wilk W test. I transformed all non-normal variables using a log, square root, or power transformation. Transformations were successful unless otherwise noted. I used the Levene test to examine all microhabitat, landscape, and disturbance variables for homogeneity of variance. All variables met the assumption of homogeneity of variance.

\section{Presence/absence relative to microhabitat and disturbance variables}

I used ANOVA to test for differences in microhabitat and disturbance variables between point count stations where Cerulean Warblers were present and point count stations where they were absent. Microhabitat ANOVA models included each microhabitat variable as the dependent variable and presence/absence as the independent treatment variable, blocking for differences among mines.

Disturbance variables were placed into categories (canopy gap, linear, pole forest, twoage cut, and selective cut) based on shape, structure, and type of disturbance (Table 2) to 
increase sample size for analyses. The disturbance ANOVA models included area of each disturbance category as the dependent variable and presence/absence as the independent treatment variable, blocking for differences among mines.

\section{Abundance and percent occurrence relative to distance}

I used regression techniques to relate Cerulean Warbler abundance to distance from reclaimed mine edge. Abundance was the maximum number of Cerulean Warblers detected at a specific point count station during the 2 counts. The regression model included abundance as the dependent variable and distance as the independent variable while blocking for effects of mines and slope position. Superior fit to the data was obtained by rerunning this model using the second-order equation (distance*distance) as the independent variable.

I used ANOVA to relate Cerulean Warbler percent occurrence to distance from reclaimed mine edge. I defined percent occurrence as the percentage of points at which Cerulean Warblers were detected within a particular distance category. For this analysis, I combined points into distance categories because number of sample points at a given distance generally was low, often with only 1 or 2 points at a given distance, particularly beyond $1140 \mathrm{~m}$. The ANOVA model included percent occurrence as the dependent variable, blocked for effects of mines and slope position, and used distance category as the independent categorical variable.

\section{Abundance and percent occurrence relative to slope position}

I used ANCOVA to compare Cerulean Warbler abundance among the 3 slope positions. The ANCOVA model included abundance at each of the point count stations as the dependent variable, slope position as the independent categorical variable, distance as the covariate, while blocking for effects of mines. Superior fit to the data was obtained by rerunning this model using the second-order equation (distance*distance) as the covariate. 
I used ANOVA to compare Cerulean Warbler percent occurrence to slope position. The ANOVA model included mean percent occurrence at the 3 slope positions as the dependent variable, slope position as the independent categorical variable, while blocking for mine effects.

\section{Abundance and percent occurrence relative to landscape metrics}

I was unable to analyze percent occurrence relative to landscape metrics because Cerulean Warblers were present at all clusters. Instead I classified clusters into 2 groups, those where Cerulean Warbler mean abundance at each cluster was $\leq 1 \quad(n=13$, mean $=0.51$, range $=0.25$ $1.00)$ and clusters where mean abundance was $>1(n=8$, mean $=1.60$, range $=1.33-2.33)$. I then used ANOVA to test for differences in landscape variables between clusters of points. The ANOVA model included each landscape variable as the dependent variable and abundance category (i.e. $\leq 1$ or $>1$ ) as the independent variable, while blocking for effects of mines.

I used regression techniques to compare Cerulean Warbler mean abundance at each cluster to percent forest cover (deciduous forest cover and mixed coniferous-deciduous forest cover combined), percent deciduous forest cover, and amount of forest core area. Percentages are the amount of forest cover within a $3 \mathrm{~km}$ radius of the cluster centroid. Regression models included mean abundance as the dependent variable and each landscape metric as the independent variables, while blocking for effects of mines.

\section{Microhabitat and landscape models}

I used an information-theoretic approach to develop microhabitat and landscape models. The information-theoretic approach is based on a principle of parsimony, suggesting the model variables, structure, and number of variables in the model should be as simple as possible (Burnham and Anderson 1998). Rather than null hypothesis testing, Burnham and Anderson (1998) recommend the use of Kullback-Leibler information and Aikaike's Information Criterion 
(AIC) as the basis for modeling. The variables I selected for my a priori models were based on previous research (Lynch 1981, Robbins et al. 1992, Oliarnyk and Robertson 1996, Hamel 1998, Hamel et al. 1998, Hamel 2000b, Rosenberg et al. 2000, Tallman 2001, Weakland and Wood 2002) and what was deemed as potentially important to Cerulean Warblers (Burnham and Anderson 1998). I evaluated the models by comparing relative AIC values and relative Aikaike weights among models (Burnham and Anderson 1998).

Microhabitat candidate models $(\mathrm{n}=176)$ included 10 individual microhabitat variables, all possible combinations of 2 and 3 variables, and all 10 variables in the full model. Microhabitat variables included in candidate models were aspect, percent slope, distance from reclaimed mine edge, snags ( $>8 \mathrm{~cm} \mathrm{dbh})$, saplings $(<3 \mathrm{~cm}$ diameter at $10 \mathrm{~cm}$ above ground and $>0.5 \mathrm{~m}$ tall), large trees (>38 cm dbh), percent canopy cover (>24 $\mathrm{m}$ in height), vertical complexity, slope position, and total amount of canopy disturbance.

Landscape candidate models $(\mathrm{n}=42)$ included 6 individual landscape variables, all possible combinations of 2 and 3 variables, and all 6 variables in the full model. Landscape variables included in candidate models were distance from cluster centroid to reclaimed mine edge, percent deciduous forest cover, percent mixed coniferous-deciduous forest cover, mean patch size of forest patches, edge density, and total forest core area.

Logistic regression was used to model Cerulean Warbler presence/absence relative to all microhabitat variables and combinations. Poisson regression was used to model Cerulean Warbler abundance relative to all microhabitat variables and combinations because the frequency was found to be a Poisson distribution (Neter et al. 1988). Linear regression was used to model Cerulean Warbler mean abundance relative to all landscape variables and combinations. Using 
AIC values plus a calculated correction factor, the 5 best models were selected and weighted for each analysis.

\section{RESULTS}

\section{Abundance and percent occurrence}

Cerulean Warbler abundance increased significantly $\left(R^{2}=0.22, F=3.51, P=0.06\right)$ with distance from reclaimed mine edge (Figure 8), particularly within $1150 \mathrm{~m}$ of the mine edge $\left(R^{2}=0.30, F=7.53, P=0.01\right)$. However superior fit to the model relating abundance to all distances from reclaimed mine edge was provided by using the second-order equation (distance*distance) $\left(R^{2}=0.28, F=7.10, P=0.01\right)$. Percent occurrence relative to distance from mine edge was not significant $(F=0.46, P=0.94)$ (Figure 9).

Mean abundance was significantly greater on ridges than bottomlands $(\mathrm{F}=2.82, \mathrm{P}=0.06)$ (Figure 10). However superior fit to the model relating abundance to slope position was provided by using the second-order equation (distance*distance) $(F=3.85, P=0.02)$. Percent occurrence did not differ statistically among the three slope positions $(F=2.05, P=0.24)$ but followed a trend similar to abundance (Table 4).

\section{Microhabitat and landscape characteristics}

Four microhabitat characteristics differed between points where Cerulean Warblers were present versus absent (Table 5). They were present on northwest to east facing slopes $(F=13.97$, $P=0.0003)$, with higher average canopy height $(F=4.07, P=0.05)$, much less sapling density $(F=5.13, P=0.03)$, and greater percent upper canopy cover $>24 \mathrm{~m}$ in height $(F=4.56, P=0.04)$.

Numerous canopy disturbances occurred at points both with and without Cerulean Warblers (Table 6). There was no relationship with occurrence relative to amount or type of disturbance. 
Of the 21 clusters of points used for landscape analyses, all had Cerulean Warblers present. Therefore I could not examine landscape characteristics relative to presence/absence. Instead I compared landscape characteristics of clusters with mean abundance $\leq 1$ to those with mean abundance $>1$ (Table 7). Three variables differed among these 2 groups. Cerulean Warbler mean abundance was greater where clusters were further from reclaimed mine edge $(F=4.18, P=0.06)$, when percent deciduous forest cover was greater $(F=3.33, P=0.09)$, and percent coniferous-deciduous forest cover was greater $(F=3.19, P=0.09)$. Mean abundance also increased significantly with percent forest cover (mixed coniferous-deciduous and deciduous forest covers combined) $\left(R^{2}=0.52, F=4.52, P=0.05\right)$ (Figure 11), percent deciduous forest cover $\left(R^{2}=0.51, F=4.19, P=0.06\right)$ (Figure 12), and forest core area $\left(R^{2}=0.52, F=4.59, P=0.05\right)$ (Figure 13).

\section{Microhabitat and landscape models}

The best 5 models relating microhabitat variables to Cerulean Warbler presence/absence all indicated a positive association with aspect (Table 8). Cerulean Warblers generally occurred on northwest to east facing slopes (Table 5). Of the 69 points where Cerulean Warblers were present, 70 percent of the points were on northwest to east facing slopes (Figure 14). The top 3 models all included a positive association with slope position. A negative association with sapling density occurred in 2 models as did a positive association with density of snags. The best model indicated Cerulean Warblers were more likely to occur on northwest to east facing slopes, with lower sapling density, and on mid-slopes and ridges. The Aikaike weight of the best model was 0.098 relative to the other 175 candidate models, indicating only a 10 percent probability of this model being chosen given the data. Subsequent models had lower weights, with $\leq 5$ percent probability of being chosen. 
The best 5 models relating microhabitat variables to Cerulean Warbler abundance all indicated a positive association with aspect and snag density (Table 9). The best model indicated abundance was more likely to be greater on northwest to southeast facing slopes, with increased snag density and amount of canopy disturbance. In addition to the positive associations of aspect and snag density, one model indicated a positive association with slope position and one indicated a positive association with distance from reclaimed mine edge, while another model showed a negative association with sapling density. The Aikaike weight of the best model was 0.18 relative to the other 175 candidate models, indicating an 18 percent probability of this model being chosen given the data. Subsequent models had lower weights, with $\leq 15$ percent probability of being chosen.

The best 5 models relating landscape variables to Cerulean warbler mean abundance did not have a distinctive variable occurring in all models (Table 10). However commonalties existed among models. In 4 of the 5 models mean abundance was positively associated with percent mixed coniferous-deciduous forest cover, while edge density had a negative association. The best model indicated mean abundance increased with percent mixed coniferous-deciduous and decreased with edge density. The best model has an Aikaike weight of 0.12 , indicating a 12 percent probability of this model being chosen given the data. The next best model has a similar Aikaike weight of 0.11 . This model indicated mean abundance increased with percent forest cover (mixed coniferous-deciduous and deciduous forest covers combined) and decreased with edge density. The remaining models also have relatively similar weights, with $\leq 10$ percent probability of being chosen. 


\section{DISCUSSION}

Cerulean Warblers reach highest breeding densities, an estimated 47 percent of the total population range wide, in the Ohio Hills physiographic area (Rosenberg 2000 unpublished data). In West Virginia, highest densities occur throughout the Ohio Hills and Cumberland Plateau physiographic provinces (Rosenberg et al. 2000), both of which encompass my study sites and the MTMVF region. Fragmentation continues to progress throughout the extensive deciduous forest stands in southwestern West Virginia as a result of the large-scale impacts from MTMVF and its associated development. Consequently, Cerulean Warbler core habitat is disappearing and remnant forest fragments and large-scale edge in reclaimed mine landscapes continue to negatively affect Cerulean Warblers. Extensively forested regions such as the central Appalachians or states such as West Virginia that may be serving as population sources are vitally important for the conservation of Cerulean Warblers. Continual loss or fragmentation of forested habitat may have negative ramifications on regional populations of some forest birds (Temple and Carey 1988, Donovan et al. 1995).

\section{Distance to edge}

Cerulean Warbler abundance increased significantly with distance from reclaimed mine edge; thus, effects of MTMVF on abundance appeared to extend beyond the reclaimed edge. Weakland and Wood (2002) found a similar trend with territory density on the same 3 study sites. They found that Cerulean Warbler territory density increased significantly with distance from reclaimed mine edge. Beyond the 1030-1150 m distance category in my study, abundance sharply decreased then again increased with distance from reclaimed mine edge. Beyond this distance category, other factors such as microhabitat variables and/or landscape metrics, besides distance to mine edge, may be contributing to Cerulean Warbler abundance. The bimodal 
response also may be a product of study design. Distances beyond $1140 \mathrm{~m}$ were less sampled and were used primarily for landscape habitat analyses.

I found no relation with percent occurrence relative to distance from reclaimed mine edge. This suggests a degree of tolerance to the large-scale edge created by MTMVF.

Although Cerulean Warblers appeared to show a degree of tolerance, territory density (Weakland and Wood 2002) and abundance increased significantly with distance from reclaimed mine edge. King et al. (1997) suggested that lower abundance of forest birds in edge areas may be a product of the absence of suitable habitat beyond the clearcut borders in their study. This is consistent with Kroodsma (1984) and Rich et al. (1994) who suggested the restriction of forest birds to mature forest habitat may result in lower abundance near edge, rather than edge avoidance. Therefore lower Cerulean Warbler abundance near reclaimed mine edge could be a result of the absence of suitable habitat near the edge.

An alternative explanation for the presence and lower abundance of Cerulean Warblers at or near the edge may be that unpaired singing males are displaced into less suitable habitat. Changes in physical conditions near edge and physiological tolerances of species may result in changes in abundance and distribution of species in relation to edge (Murcia 1995). Additionally edge may increase predation, brood parasitism, and competition among species (Faaborg et al. 1995), thus decreasing habitat suitability for Cerulean Warblers well beyond the MTMVF border.

\section{Slope position}

Although high abundances of Cerulean Warblers were historically found in broad river valleys such as the Ohio and Mississippi River valleys (Hamel 2000a), they have been increasingly found in a variety of forested habitats at various slope positions. It appears that in relatively flat landscapes Cerulean Warblers tend to be found in areas with vertical complexity 
and large trees. In the Roanoke River basin of northeastern North Carolina, Lynch (1981) found that Cerulean Warbler males characteristically used the tallest canopy trees available for singing perches. Furthermore, Lynch (1981) suggested good development of vegetative strata or functional layers such as canopy, subcanopy, shrub, and ground cover was a minimum habitat requirement for Cerulean Warblers along the Roanoke River basin. In bottomland hardwood forests of western Tennessee, Cerulean Warbler males were found perched in significantly larger trees relative to available trees in their study site (Robbins et al. 1992). However, work in the Mississippi Alluvial Valley suggested individual values or heights of canopy cover may not be the constraining factor, vertical distribution of the canopy foliage may be more important (Hamel 2000b).

In mountainous landscapes, Cerulean Warblers appear to use ridgetops as the source of vertical complexity, possibly allowing their song to project further into surrounding habitat. Mean abundance of Cerulean Warblers was significantly greater on ridges than bottomlands (Figure 10). Additionally, percent occurrence tended to be greater on ridges (Table 4), although not significantly so. Similar findings in West Virginia by Rosenberg et al. (2000) and Weakland and Wood (2002) show Cerulean Warblers occupy ridges more so than bottomlands. This suggests ridges are an important habitat component in southwestern West Virginia. Consequently, disturbances such as MTMVF in which ridges are removed may have a greater impact on populations compared to sources of fragmentation where ridges are not disturbed.

\section{Microhabitat}

Cerulean Warbler abundance was positively related with northwest to southeast facing

slopes, increasing snag density, and increasing amount of disturbance in the canopy. Aspect and snag density appeared in the best 5 microhabitat models (Table 9). Amount of canopy 
disturbance also was included in the best microhabitat model. Similarly, presence of Cerulean Warblers was positively related to northwest to east facing slopes, lower sapling density, and ridges. Aspect again occurred in the best five models (Table 8).

Aspect was important for Cerulean Warbler abundance and presence in my study sites. Previous research suggests that forest growth in the northern hemisphere is frequently greatest on north to east facing slopes (Beers et al. 1966, Graney 1978). Cerulean Warblers appeared to show a preference for northwest to east facing slopes on my study sites (Figure 14). Site productivity could be correlated to greater canopy heights and greater canopy cover beyond 24 $\mathrm{m}$, allowing minimal sunlight to penetrate, resulting in lower sapling density (Table 5). Hamel et al. (1998) also found larger trees and lower sapling densities on sites with Cerulean Warblers than sites without.

Snag density was important to both presence and abundance of Cerulean Warblers in my study and to territory density in a study by Weakland and Wood (2002). Snags may contribute to structural complexity in the canopy and large snags may temporarily increase the amount of canopy gaps in a forest stand. Snag density in both of these studies, however, included all dead trees $>8 \mathrm{~cm}$ dbh within a 0.04 ha circular vegetative plot. Thus some of these snags likely only contributed to mid-story or lower canopy vegetative layers. More research is needed to determine if Cerulean Warblers are showing preferences for areas where snags have created openings in the canopy allowing for understory development or areas where snags have opened up the understory leaving a dense upper canopy cover.

Amount of canopy disturbance was important to abundance of Cerulean Warblers in my study. Other researchers also have suggested that gaps or openings in the forest canopy may be important to Cerulean Warblers (Oliarnyk 1996, Oliarnyk and Robertson 1996). Similarly, 
Weakland and Wood (2002) found Cerulean Warblers were not avoiding internal edges such as open and partially-open trails and roads and natural tree fall gaps. However, Cerulean Warblers did not show a distinct preference for a particular amount or type of canopy disturbance within my study area. I found high amounts of canopy disturbance throughout all of my study sites, which contributed to overall heterogeneity and structural complexity of the forest stands.

Structural complexity appears to be a more important habitat requirement than a specific amount or type of canopy disturbance.

\section{Landscape}

Cerulean Warbler mean abundance increased with percent mixed coniferous-deciduous forest cover and decreased with edge density. Strikingly, 4 of the 5 best models indicate mean abundance is positively related to percent mixed coniferous-deciduous (Table 10). Previous literature suggests a negative relationship between abundance and percent canopy cover of conifers (Robbins 1989). Additionally, Weakland and Wood (2002) found territory density was negatively associated with percent mixed coniferous-deciduous forest cover. In my study, mixed coniferous-deciduous forest cover only ranged from 1.43-10.15 percent at all clusters (Table 7). Therefore, minimal percentages of mixed coniferous-deciduous forest within the landscape do not appear to affect use of the area by Cerulean Warblers.

More consistent with previous literature, Cerulean Warbler mean abundance increased with percent forest cover (mixed coniferous-deciduous and deciduous forest covers combined), percent deciduous forest cover, and amount of forest core area. Robbins et al. (1989) and Robbins et al. (1992) found Cerulean Warblers to occur in large blocks of mature deciduous forest. Territory density was positively correlated with forest core area (Weakland and Wood 
2002). Hamel et al. (1998) associated Cerulean Warbler occurrence with sites significantly more forested than sites where birds were not detected.

Edge density also appeared in 4 of the best 5 landscape models describing the relationship between mean abundance and landscape variables (Table 10). Cerulean Warblers were less abundant in landscapes containing greater amounts of edge created by disturbances larger than $26 \mathrm{~m}$ in diameter. Large-scale edge created by MTMVF accounted for most of the edge density in the reclaimed mine landscape with other large disturbances (i.e. main powerline corridors, major roads and/or highways, residential areas, and few pasture fields) contributing much less (Figure 7).

\section{Conclusions}

On my study sites in southwestern West Virginia, Cerulean Warblers appeared to prefer areas on northwest to east facing slopes and ridgetops with high snag density and low sapling density within large blocks of mature deciduous forest. Similar to Weakland and Wood (2002), I found that Cerulean Warblers are not avoiding canopy disturbances such as open and partiallyopen trails and roads and natural tree fall gaps. However, my study and Weakland and Wood's (2002) study both indicate Cerulean Warbler densities increase with distance to reclaimed mine edge. Since presence/abundance data based on point counts does not imply birds breed in an area, similarity between Weakland and Woods (2002) territory density data and my abundance data at the microhabitat and landscape levels contributes to the validity and strength of my results.

Although effects of habitat fragmentation are proportional to the overall amount of forest cover in a landscape (Hamel 2000a), large-scale disturbances in the core of the Cerulean Warbler breeding range may have detrimental effects on their populations. Cerulean Warbler continued 
survival and productivity requires interior forest habitat (Robbins et al. 1989). Mountaintop mining/valley fill alters the spatial configuration of habitats in southwestern West Virginia, creating edge that negatively affects Cerulean Warbler abundance and distribution in the reclaimed mine landscape. Continued alteration of the spatial configuration of habitat from fragmentation could result in population subdivisions and the creation of metapopulations, which could in turn affect the stability and persistence of the population (Gilpin 1991). In addition to decreasing Cerulean Warbler habitat suitability of the remaining forest, MTMVF converts large amounts of suitable deciduous forest habitat to unsuitable primary succession vegetative communities. Therefore loss of mature deciduous forest in southwestern West Virginia could displace Cerulean Warblers to less suitable fragmented habitat, which has been shown to negatively affect their territory density, abundance, and distribution. 


\section{LITERATURE CITED}

Askins, R. A., J. F. Lynch, and R. Greenburg. 1990. Population declines in migratory birds in eastern North America. Current Ornithology 7:1-57.

Balcerzak, M. J., and P. B. Wood. 2003. Red-shouldered hawk (Buteo lineatus) abundance and habitat in a reclaimed mine landscape. Journal of Raptor Research 37:188-197.

Barbour, M. G., J. H. Burk, W. D. pitts, F. S. Gilliam, and M. W. Schwartz. 1999. Terrestrial plant ecology. Third edition. Benjamin/Cummings, Menlo Park, CA., U. S. A.

Bart, J., and J. D. Schoultz. 1984. Reliability of singing bird surveys: changes in observer efficiency with avian density. Auk 101:307-318.

Beers, T. W., P. E. Dress, and L. C. Wensel. 1966. Notes and observations. Aspect transformation in site productivity research. Journal of Forestry 64:691-692.

Burnham K. P., and D. R. Anderson. 1998. Model selection and inference: a practical information-theoretic approach. Springer-Verlag New York, New York, NY., U. S. A.

Caughley, G., and A. Gunn. 1995. Conservation biology in theory and practice. Blackwell Science, Cambridge, Mass., U. S. A.

Donovan, T. M., F. R. Thompson III, J. Faaborg, and J. R. Probst. 1995. Reproductive success of migratory birds in habitat sources and sinks. Conservation Biology 9:1380-1395.

Elkie, P., R. Rempel, and A. Carr. 1999. Patch analyst user's manual. Ontario Ministry of Natural Resources. Northwest Science and Technology. Thunder Bay, Ontario, Canada.

Environmetal Systems Research Institute. 1996. Using ArcView ${ }^{\circledR}$ GIS. Enivironmental Systems Research Institute, Redlands, CA., U. S. A. 
Faaborg, J., M. Brittingham, T. Donovan, and J. Blake. 1995. Habitat fragmentation in the temperate zone. Pp. 357-379 in T. E. Martin and D. M. Finch, Editors. Ecology and management of neotropical migratory birds, Oxford University Press, New York, N.Y., U.S.A.

Fedorko N., and M. Blake. 1998. A geologic overview of mountaintop removal mining in West Virginia. Executive Summary of a report to the Committee on Post-Mining Land Use and Economic Aspects of Mountaintop Removal Mining. West Virginia Geological and Economic Survey, Morgantown, WV, U. S. A.

Gates, J. E., and D. R. Evans. 1998. Cowbirds breeding in the central Appalachians: spatial and temporal patterns and habitat selection. Ecological Applications 8:27-40.

Gilpin, M. E. 1991. The genetic effective size of a metapopulation. Pp. 165-175 in M. E. Gilpin, and I. Hanski, Editors. Metapopulation dynamics: Empirical and theoretical investigations. Academic Press, London.

Graney, D. L. 1978. Site quality relationships for oak-hickory forest types. Proceedings of 1978 Society of American Foresters National Convention. Pp. 339-343.

Guthery, F. S., and R. L. Bingham. 1992. On Leopold's principle of edge. Wildlife Society Bulletin 20:340-344.

Hamel, P. B. 1998. Landscape and habitat distribution of the Cerulean Warbler Dendroica cerulea in extensively fragmented Mississippi alluvial valley, U.S.A. Ostrich 69:286

Hamel, P. B., R. J. Cooper, and W. P. Smith. 1998. The uncertain future for Cerulean Warblers in the Mississippi Alluvial Valley. Pp. 95-109 in Proceedings of conference The Delta: Connecting Points of View for Sustainable Natural Resources, 13-16 August 1996, Memphis, TN., U. S. A. 
Hamel, P. B. 2000a. Cerulean Warbler (Dendroica cerulea). In A. Poole and F. Gills, Editors. The birds of North America, No. 511. Academy of Natural Sciences, Philadelphia, and American Ornithologists' Union, Washington, D.C., U.S.A.

Hamel, P. B. 2000b. Cerulean Warbler Status Assessment. U. S. Forest Service Southern Research Station, Stoneville, MISS., U.S.A.

Hicks, R. R., Jr. 1998. Ecology and management of central hardwood forests. Pp 97-98. John Wiley \& Sons, Inc. New York, NY., U.S.A.

Hunter, M. L., Jr. 1990. Edges. Pp. 101-114 in Wildlife, forests, and forestry: principles of managing forests for biological diversity. Prentice-Hall, Inc. Englewood Cliffs, NJ., U.S.A.

James, F. C. and H. H. Shugart. 1970. A quantitative method of habitat description. Audubon Field Notes 24:727-736.

Jones, J., W. J. McLeish, and R. J. Robertson. 2000. Density influences census technique accuracy for Cerulean Warblers in eastern Ontario. Journal of Field Ornithology 71:4656.

King, D. I., C. R. Griffin, and R. M. DeGraaf. 1997. Effect of clearcut borders on distribution and abundance of forest birds in northern New Hampshire. The Wilson Bulletin 109:239-245.

Kroodsma, R. L. 1984. Effect of edge on breeding forest bird species. The Wilson Bulletin 96:426-436.

Leopold, A. 1933. Game management. Charles Scribner's Son, New York, NY., U. S. A.

Lynch, J. M. 1981. Status of the Cerulean Warbler in the Roanoke River basin of North Carolina. Chat 45:29-35. 
Manolis, J. C., D. E. Andersen, and F. J. Cuthbert. 2000. Patterns in clearcut edge and fragmentation effect studies in northern hardwood-conifer landscapes: retrospective power analysis and Minnesota results. Wildlife Society Bulletin 28:1088-1101.

Martin, T. E., C. R. Paine, C. J. Conway, W. M. Hochachka, P. Allen, and W. Jenkins. 1997. BBIRD Field Protocol. Montana Cooperative Wildlife Research Unit, University of Montana, Missoula, MT., U. S. A.

McGarigal, K., and B. J. Marks. 1994. FRAGSTATS: spatial pattern analysis program for quantifying landscape structure. U. S. Forest Service General Technical Report PNW 351.

Minckler, L. S., and J. D. Woerheide. 1965. Reproduction of hardwoods 10 years after cutting as affected by site and opening size. Journal of Forestry 63:103-107.

Murcia C. 1995. Edge effects in fragmented forests: implications for conservation. Trends in Ecology and Evolution 10:58-62.

Musgrave, R. S., J. Flynn-O'Brien, P. A. Lambert, and Smith. 1998. Federal wildlife laws handbook with related laws/Center for Wildlife Law at the Institute of Public Law, School of Law, University of New Mexico, E. Crawford and C. Byers, Editors. Government Institute, Inc., Rockville, MD., U.S.A.

Nebel, B. J., and R. T. Wright. 1998. Pp. 97-102 in Environmental science. Sixth edition. Prentice-Hall, Inc., Upper Saddle River, NJ., U.S.A.

Neter, J., W. Wasserman, and G. A. Whitmore. 1988. Applied statistics. Allyn and Bacon, Inc., Boston, MASS., U.S.A.

Oliarnyk, C. J. 1996. Habitat selection and reproductive success of Cerulean Warblers in southeastern Ontario. M. S. Thesis, Queen's University, Kingston, Ontario, Canada. 
Oliarnyk, C. J., and R. J. Robertson. 1996. Breeding behavior and reproductive success of Cerulean Warblers in southeastern Ontario. Wilson Bulletin 108:673-684.

Paton, P. W. C. 1994. The effects of edge on avian nest success: how strong is the evidence? Conservation Biology 8:17-26.

Ralph, C. J., G. R. Guepel, P. Pyle, T. E. Martin, and D. F. Desante. 1993. Handbook of field methods for monitoring landbirds. US Forest Service General Technical Report PSWGTR-144.

Rich, A. C., D. S. Dobkin, and L. J. Niles. 1994. Defining forest fragmentation by corridor width: the influence of narrow forest-dividing corridors on forest-nesting birds in New Jersey. Conservation Biology 8:1109-1121.

Robbins, C.S., D. Bystrak, and P.H. Geissler. 1986. Pp. 196 in The breeding bird survey: its first fifteen years, 1965-1979. U.S. Fish and Wildlife Service Resource Publication 157, Washington, D. C.

Robbins, C. S., D. K. Dawson, and B. A. Dowell. 1989. Habitat area requirements of breeding forest birds of the middle Atlantic states. Wildlife Monographs 103:1-34.

Robbins, C. S., J. W. Fitzpatrick, and P. B. Hamel. 1992. A warbler in trouble: Dendroica cerulea. Pp. 549-562 in J. M. Hagan, III and D. W. Johnson, Editors. Ecology and conservation of neotropical landbirds, Smithsonian Institution Press, Washington, D.C., U.S.A.

Robinson, S. K. 1993. Conservation problems of neotropical migrant land birds. Transactions North American Wildlife and Natural Resources Conference 58:379-389. 
Robinson, S. K., F. R. Thompson III, T. M. Donovan, D. R. Whitehead, and J. Faaborg. 1995. Regional forest fragmentation and the nesting success of migratory birds. Science 267:1987-1990.

Rosenberg, K. V. 2000. Partners in Flight landbird conservation plan: physiographic area 22: Ohio Hills. Unpublished Draft.

Rosenberg, K. V., S. E. Barker, and R. W. Rohrbaugh. 2000. An atlas of Cerulean Warbler populations. Final Report to the U. S. Fish and Wildlife Service, Cornell Lab of Ornithology, Ithaca, N. Y., U.S.A.

Rosenberg, K. V., and J. V. Wells. 2000. Global perspectives on neotropical migrant conservation in the Northeast: long-term responsibility vs. immediate concern. In R. Bonney, D. N. Pashley, R. J. Cooper, and L. Niles, Editors. Strategies for bird conservation: the Partners in Flight planning process. Proceedings of the 3rd Partners in Flight Workshop, October 1995, Cape May, N.J. Proceedings RMRS-P-16. Department of Agriculture, U.S.D.A. Forest Service, Rocky Mountain Research Station, Ogden, Utah.

SAS Institute Inc. 1991. SAS/STAT Guide for personal computers. Version 6. SAS Institute, Inc. Cary, NC., U. S. A.

Sauer, J. R., J. E. Hines, and J. Fallon. 2001. The North American Breeding Bird Survey, results and analysis 1966 - 2000. Version 2001.2, U.S.G.S. Patuxent Wildlife Research Center, Laurel, MD., U.S.A.

Saunders, D. A., R. J. Hobbs, and C. R. Margules. 1991. Biological consequences of ecosystem fragmentation: a review. Conservation Biology 5:18-32. 
Smith, W. B., J. S. Vissage, D. R. Darr, and R. M. Sheffield. 2001. Forest resources of the United States, 1997. General Technical Report NC-219, USDA Forest Service, North Central Research Station. St. Paul, MN., U.S.A.

Strausbaugh, P. D. and E. L. Core. 1977. Flora of West Virginia. Seneca Books Inc., Morgantown, WV., U.S.A.

Tallman, R. E. 2001. Habitat characteristics of the Cerulean Warbler (Dendroica cerulea) in West Virginia: development of a predictive model. Master's Thesis, Frostburg State University, MD., U.S.A.

Temple, S. A. and J. R. Carey. 1988. Modeling dynamics of habitat interior bird populations in fragmented landscapes. Conservation Biology 2:340-347.

United States Department of Agriculture Soil Conservation Service. 1981. Soil survey of Kanawha County, West Virginia. 0 - 254-032. United State Government Printing Office, Washington, D.C., U. S. A.

United States Department of Agriculture Soil Conservation Service. 1994. Soil survey of Boone County, West Virginia. 1994-300-438/00006. United State Government Printing Office, Washington, D.C., U. S. A.

United States Environmental Protection Agency. 2000. Mountaintop mining/valley fill environmental impact statement. Preliminary Draft. January 2001, EPA/903/R-00/013, Environmental Protection Agency Region 3, Philadelphia, PA., U.S.A.

Verner, J., and K. A. Milne. 1989. Coping with sources of variability when monitoring population trends. Annual Zoological Fennici. 26:191-199. 
Weakland, C. A. and P. B. Wood. 2002. Cerulean Warbler (Dendroica cerulea) microhabitat and landscape-level habitat characteristics in southern West Virginia in relation to mountaintop mining/valley fills. Final Project Report. December 2002.

Yahner, R. H. 1988. Changes in wildlife communities near edges. Conservation Biology 2:333339. 
Table 1. Abbreviations and descriptions of microhabitat variables measured at vegetation plots in southwestern West Virginia, 2002.

\begin{tabular}{|c|c|}
\hline Variable & Description \\
\hline ASPECTCO & $\begin{array}{l}\text { Transformed aspect code using Beers (1966) transformation } \mathrm{A}^{\prime}=\cos (45-\mathrm{A})+1 \text {. } \\
\text { Values can range from } 0 \text { to } 2 \text {, with } 2 \text { indicating northeast facing slope. }\end{array}$ \\
\hline SLOPE & Percent slope (gradient), measured with a clinometer. \\
\hline DIST & Distance $(\mathrm{m})$ from reclaimed mine edge. \\
\hline CAN_HGHT & Average canopy height (m) of 0.04 ha plot, measured with a clinometer. \\
\hline SPOSITION & Slope position (bottomland, mid-slope, or ridge) \\
\hline \multicolumn{2}{|l|}{ Ground Cover } \\
\hline GREEN & Percent green ground cover within 0.04 ha plot. \\
\hline LITTER & Percent litter ground cover within 0.04 ha plot. \\
\hline WOOD & Percent woody debris ground cover within 0.04 ha plot. \\
\hline BARE & Percent bare ground cover within 0.04 ha plot. \\
\hline MOSS & Percent moss ground cover within 0.04 ha plot. \\
\hline \multicolumn{2}{|l|}{ Stem Density } \\
\hline SNAG_3 & $\begin{array}{l}\text { Number of dead stems per } 0.008 \text { ha plot }>3 \mathrm{~cm} \text {, but }<8 \mathrm{~cm} \text { diameter at } 10 \mathrm{~cm} \text { above } \\
\text { ground and }>0.5 \mathrm{~m} \text { tall. }\end{array}$ \\
\hline SNAG_4 & Number of dead trees $\geq 8 \mathrm{~cm}$ dbh within 0.04 ha plot. \\
\hline SAPLINGS & $\begin{array}{l}\text { Number of stems per } 0.008 \text { ha plot }<3 \mathrm{~cm} \text { diameter at } 10 \mathrm{~cm} \text { above ground and }>0.5 \mathrm{~m} \\
\text { tall. }\end{array}$ \\
\hline POLES & $\begin{array}{l}\text { Number of stems per } 0.008 \text { ha plot } \geq 3 \mathrm{~cm} \text {, but }<8 \mathrm{~cm} \text { diameter at } 10 \mathrm{~cm} \text { above ground } \\
\text { and }>0.5 \mathrm{~m} \text { tall. }\end{array}$ \\
\hline TREE3_9 & Number of trees $8-23 \mathrm{~cm}$ dbh within 0.04 ha plot. \\
\hline TREE9_15 & Number of trees $>23-38 \mathrm{~cm}$ dbh within 0.04 ha plot. \\
\hline TREE15_21 & Number of trees $>38-53 \mathrm{~cm}$ dbh within 0.04 ha plot. \\
\hline TREE_21 & Number of trees $>53 \mathrm{~cm}$ dbh within 0.04 ha plot. \\
\hline \multicolumn{2}{|l|}{ Canopy Cover } \\
\hline CAN05_3 & Percent canopy cover at $0.5-3 \mathrm{~m}$ height class within 0.04 ha plot. \\
\hline CAN3_6 & Percent canopy cover at $>3-6 \mathrm{~m}$ height class within 0.04 ha plot. \\
\hline CAN6_12 & Percent canopy cover at $>6-12 \mathrm{~m}$ height class within 0.04 ha plot. \\
\hline CAN12_18 & Percent canopy cover at $>12-18 \mathrm{~m}$ height class within 0.04 ha plot. \\
\hline CAN18_24 & Percent canopy cover at $>18-24 \mathrm{~m}$ height class within 0.04 ha plot. \\
\hline CAN_24 & Percent canopy cover $>24 \mathrm{~m}$ in height within 0.04 ha plot. \\
\hline \multicolumn{2}{|c|}{ Functional Layer Cover } \\
\hline SHRUB_L & Percent cover of shrub layer within 0.04 ha plot. \\
\hline MIDSTORY & Percent cover of midstory layer within 0.04 ha plot. \\
\hline L_CANOPY & Percent cover of lower canopy layer within 0.04 ha plot. \\
\hline U_CANOPY & Percent cover of upper canopy layer within 0.04 ha plot. \\
\hline VERT_COM & Sum of all functional layers present (vertical complexity) within 0.04 ha plot. \\
\hline
\end{tabular}


Table 2. Abbreviations and descriptions of disturbance types measured within $100 \mathrm{~m}$ radius of each point count station in southwestern West Virginia, 2002.

\begin{tabular}{ll}
\hline Disturbance & Description \\
\hline Linear (LINE) & Amount $\left(\mathbf{m}^{2}\right)$ of linear canopy disturbances \\
POCL & Partially open canopy gas or power line corridors \\
OCLI & Open canopy gas or power line corridors \\
OCRO & Open canopy roads \\
POCR & Partially open canopy roads \\
RIVE & Partially open canopy river or stream systems \\
STRI & Open canopy strip bench or deep mines \\
RIPA & Open canopy riparian vegetative communities \\
Canopy Gap (CANG) & Amount $\left(\mathbf{m}^{2}\right)$ of canopy gaps \\
WIND & Canopy openings created by wind throws \\
SNAG & Canopy openings created by snags \\
WASH & Canopy openings created by flooding \\
GARD & Canopy openings created by gardening or cultivation \\
GASO & Canopy openings created by gas wells or pumps \\
LOGP & Canopy openings created by timber stock piles \\
TURN & Canopy openings created by vehicles turning around \\
FIWO & Canopy openings created by firewood cutting \\
Timber Harvest & Amount $\left(\mathbf{m}^{2}\right)$ of timber harvesting or successional forest type \\
POLE & Deciduous pole forest is young deciduous trees with an estimated 10-20 cm dbh \\
TACU & Two-age stand, an area where deciduous trees had two different age classes. Areas \\
& tended to have scattered mature deciduous trees $>30 \mathrm{~cm}$ dbh and were interspersed \\
& with young deciduous trees with an estimated 10-30 cm dbh depending on age and \\
SECU & location of cut. \\
& Selective harvest, an area where large mature tree species such as black walnut \\
Overall (DAREA) & (Juglans nigra), black cherry (Prunus serotina), and/or red oak $(Q$ uercus rubra $)$ were \\
\hline & selectively removed. \\
Amount $\left(\mathbf{m}^{2}\right)$ of total canopy disturbance
\end{tabular}


Table 3. Descriptions of landscape variables measured within $3 \mathrm{~km}$ radius circular plot from each cluster centroid in southwestern West Virginia, 2002.

\begin{tabular}{|c|c|}
\hline Variable & Description \\
\hline CDIST & Distance $(\mathrm{m})$ from cluster centroid to reclaimed mine edge \\
\hline \multicolumn{2}{|l|}{ Land Cover } \\
\hline$\%$ DECID & Percent deciduous forest cover \\
\hline$\%$ MIXED & Percent mixed coniferous-deciduous forest cover \\
\hline$\% \mathrm{NON}$ & $\begin{array}{l}\text { Percent non-forest cover (grassland/barren, water, developed, road, riparian, and early-successional } \\
\text { cover types with a minimum diameter of } 26 \mathrm{~m} \text { ) }\end{array}$ \\
\hline SDI & $\begin{array}{l}\text { Shannon's diversity index or relative measure of patch diversity based on } 3 \text { land cover types. Index } \\
\text { equals zero if only one patch type is present in the landscape and increases with the increase of } \\
\text { patch types or proportional distribution of patch types (McGarigal and Marks 1994). }\end{array}$ \\
\hline \multicolumn{2}{|l|}{ Forest Cover } \\
\hline$\%$ FOREST & Percent forest (deciduous cover and mixed cover combined) \\
\hline MPS & Mean patch size (ha) of forest patches \\
\hline AWMSI & $\begin{array}{l}\text { Area weighted mean shape index (forest shape complexity). Value equals } 1 \text { when all patches are } \\
\text { circular and then increases with no limit as the shape of patch becomes noncircular and is weighted } \\
\text { by patch area so that larger patch areas are weighted more than smaller patches. }\end{array}$ \\
\hline ED & Edge density $(\mathrm{m} / \mathrm{ha})$ is amount of forest edge relative to the landscape area \\
\hline TCA & Total core area (ha) of forest patches using a $50 \mathrm{~m}$ edge effect buffer \\
\hline MCA & Mean core area (ha) is mean size of disjunct core area forest patches \\
\hline CAD & Core area density is number of disjunct core areas per ha \\
\hline
\end{tabular}

Table 4. Sampling effort, percentage of points with Cerulean Warblers (CERW), and abundance at each slope position in southwestern West Virginia, 2002.

\begin{tabular}{|c|c|c|c|c|c|c|}
\hline \multirow[b]{2}{*}{ Mine } & \multirow{2}{*}{$\begin{array}{c}\text { Slope } \\
\text { Position }\end{array}$} & \multirow{2}{*}{$\begin{array}{c}\text { \# of Points } \\
\text { Sampled }\end{array}$} & \multirow{2}{*}{$\begin{array}{l}\% \text { of Points } \\
\text { with CERW }\end{array}$} & \multicolumn{3}{|c|}{ Abundance } \\
\hline & & & & Mean & SE & Range \\
\hline \multirow[t]{3}{*}{ Cannelton } & Ridge & 18 & 77.8 & 1.8 & 0.3 & $0.0-5.0$ \\
\hline & Mid-slope & 18 & 77.8 & 1.3 & 0.2 & $0.0-3.0$ \\
\hline & Bottom & 6 & 66.7 & 1.0 & 0.4 & $0.0-2.0$ \\
\hline \multirow[t]{3}{*}{ Daltex } & Ridge & 10 & 50.0 & 0.6 & 0.2 & $0.0-2.0$ \\
\hline & Mid-slope & 21 & 61.9 & 0.9 & 0.2 & $0.0-3.0$ \\
\hline & Bottom & 6 & 16.7 & 0.2 & 0.2 & $0.0-1.0$ \\
\hline \multirow[t]{3}{*}{ Hobet } & Ridge & 18 & 61.1 & 0.8 & 0.2 & $0.0-2.0$ \\
\hline & Mid-slope & 20 & 35.0 & 0.5 & 0.2 & $0.0-2.0$ \\
\hline & Bottom & 5 & 40.0 & 0.4 & 0.3 & $0.0-1.0$ \\
\hline \multirow[t]{3}{*}{ Overall } & Ridge & 46 & 65.2 & 1.1 & 0.2 & $0.0-5.0$ \\
\hline & Mid-slope & 59 & 57.6 & 0.9 & 0.1 & $0.0-3.0$ \\
\hline & Bottom & 17 & 41.2 & 0.5 & 0.2 & $0.0-2.0$ \\
\hline
\end{tabular}


Table 5. Cerulean Warbler (CERW) occurrence relative to microhabitat variables measured at vegetation plots in southwestern West Virginia, 2002.

\begin{tabular}{|c|c|c|c|c|c|c|c|c|}
\hline \multirow[b]{2}{*}{ Variable } & \multicolumn{3}{|c|}{ CERW Present $(n=69)$} & \multicolumn{3}{|c|}{ CERW Absent $(n=50)$} & \multirow[b]{2}{*}{$F$} & \multirow[b]{2}{*}{$P$} \\
\hline & Mean & SE & Range & Mean & SE & Range & & \\
\hline ASPECTCO & 1.2 & 0.1 & $0.0-2.0$ & 0.8 & 0.1 & $0.0-2.0$ & 13.97 & $<0.01$ \\
\hline SLOPE & 47.6 & 1.8 & $18.5-82.0$ & 45.9 & 2.4 & $11.5-86.5$ & 1.45 & 0.23 \\
\hline DIST & 1006.2 & 112.9 & $40.0-3070.0$ & 809.3 & 118.6 & $40.0-3045.0$ & 0.79 & 0.38 \\
\hline CAN_HGHT & 26.1 & 0.4 & $19.4-31.8$ & 25.6 & 0.5 & $19.4-31.7$ & 4.07 & 0.05 \\
\hline \multicolumn{9}{|l|}{ Ground Cover } \\
\hline GREEN $^{\mathrm{a}}$ & 6.6 & 0.4 & $1.0-15.5$ & 5.6 & 0.4 & $0.5-14.0$ & 2.07 & 0.15 \\
\hline LITTER & 11.3 & 0.4 & $3.5-17.5$ & 11.9 & 0.4 & $3.5-17.0$ & 0.81 & 0.37 \\
\hline WOOD $^{\mathrm{a}}$ & 0.9 & 0.1 & $0.0-4.0$ & 0.9 & 0.1 & $0.0-3.0$ & 0.06 & 0.81 \\
\hline $\mathrm{BARE}^{\mathrm{a}}$ & 0.9 & 0.1 & $0.0-6.0$ & 1.1 & 0.2 & $0.0-4.0$ & 0.20 & 0.65 \\
\hline $\operatorname{MOSS}^{\mathrm{a}}$ & 0.3 & 0.1 & $0.0-2.0$ & 0.5 & 0.1 & $0.0-3.0$ & 0.18 & 0.67 \\
\hline \multicolumn{9}{|l|}{ Stem Density } \\
\hline SNAG_3 $3^{\mathrm{a}}$ & 1.2 & 0.2 & $0.0-7.5$ & 1.0 & 0.2 & $0.0-4.0$ & 0.66 & 0.42 \\
\hline SNAG_4 $4^{\mathrm{a}}$ & 2.4 & 0.3 & $0.0-9.0$ & 2.0 & 0.2 & $0.0-7.5$ & 0.28 & 0.60 \\
\hline SAPLINGS $^{\mathrm{b}}$ & 74.4 & 5.2 & $10.0-214.0$ & 104.3 & 12.8 & $13.0-510.5$ & 5.13 & 0.03 \\
\hline POLES $^{\mathrm{a}}$ & 5.1 & 0.4 & $0.0-15.0$ & 5.6 & 0.5 & $1.0-19.5$ & 0.65 & 0.42 \\
\hline TREE3_9 ${ }^{\mathrm{a}}$ & 15.0 & 0.8 & $3.5-30.0$ & 15.3 & 1.1 & $2.5-40.0$ & 0.07 & 0.79 \\
\hline TREE9_15 & 4.9 & 0.2 & $1.0-8.5$ & 4.9 & 0.3 & $1.0-8.5$ & 0.03 & 0.86 \\
\hline TREE15_21 ${ }^{\mathrm{a}}$ & 1.8 & 0.2 & $0.0-6.0$ & 2.0 & 0.2 & $0.0-5.5$ & 0.20 & 0.66 \\
\hline TREE_2 $1^{\mathrm{a}}$ & 0.8 & 0.1 & $0.0-3.5$ & 0.6 & 0.1 & $0.0-2.0$ & 2.49 & 0.12 \\
\hline \multicolumn{9}{|l|}{ Canopy Cover } \\
\hline CAN05_3 ${ }^{\mathrm{a}}$ & 7.6 & 0.4 & $0.5-15.5$ & 8.1 & 0.5 & $2.5-18.0$ & 0.37 & 0.54 \\
\hline CAN3_6 & 10.3 & 0.5 & $1.5-19.5$ & 11.2 & 0.5 & $6.5-19.5$ & 1.25 & 0.27 \\
\hline CAN6_12 & 13.5 & 0.3 & $6.0-19.0$ & 13.2 & 0.4 & $7.0-19.0$ & 0.03 & 0.87 \\
\hline CAN12_18 & 14.1 & 0.4 & $3.0-19.0$ & 13.8 & 0.4 & $8.0-19.0$ & 0.51 & 0.48 \\
\hline CAN18_24 ${ }^{\mathrm{c}}$ & 11.5 & 0.5 & $2.0-18.5$ & 11.9 & 0.6 & $1.0-19.0$ & 0.20 & 0.65 \\
\hline CAN_24 & 6.7 & 0.6 & $0.0-15.5$ & 5.9 & 0.7 & $0.0-15.0$ & 4.56 & 0.03 \\
\hline \multicolumn{9}{|l|}{ Functional Layer } \\
\hline SHRUB_L ${ }^{\mathrm{a}}$ & 5.0 & 0.4 & $0.0-15.5$ & 4.8 & 0.4 & $0.0-16.5$ & 0.05 & 0.83 \\
\hline MIDSTORY $^{c}$ & 17.4 & 0.3 & $7.0-20.0$ & 17.8 & 0.3 & $13.0-20.0$ & 0.01 & 0.93 \\
\hline L_CANOPY ${ }^{c}$ & 14.1 & 0.3 & $3.0-18.5$ & 13.9 & 0.4 & $5.5-18.5$ & 0.15 & 0.70 \\
\hline U_CANOPY & 10.9 & 0.5 & $2.0-18.0$ & 10.2 & 0.5 & $4.0-17.0$ & 2.29 & 0.13 \\
\hline VERT_COM ${ }^{\mathrm{c}}$ & 47.3 & 0.7 & $13.0-56.0$ & 46.7 & 0.7 & $35.5-56.5$ & 1.97 & 0.16 \\
\hline
\end{tabular}


Table 6. Cerulean Warbler (CERW) occurrence relative to type and amount of disturbance within $100 \mathrm{~m}$ radius from each point count station in southwestern West Virginia, 2002.

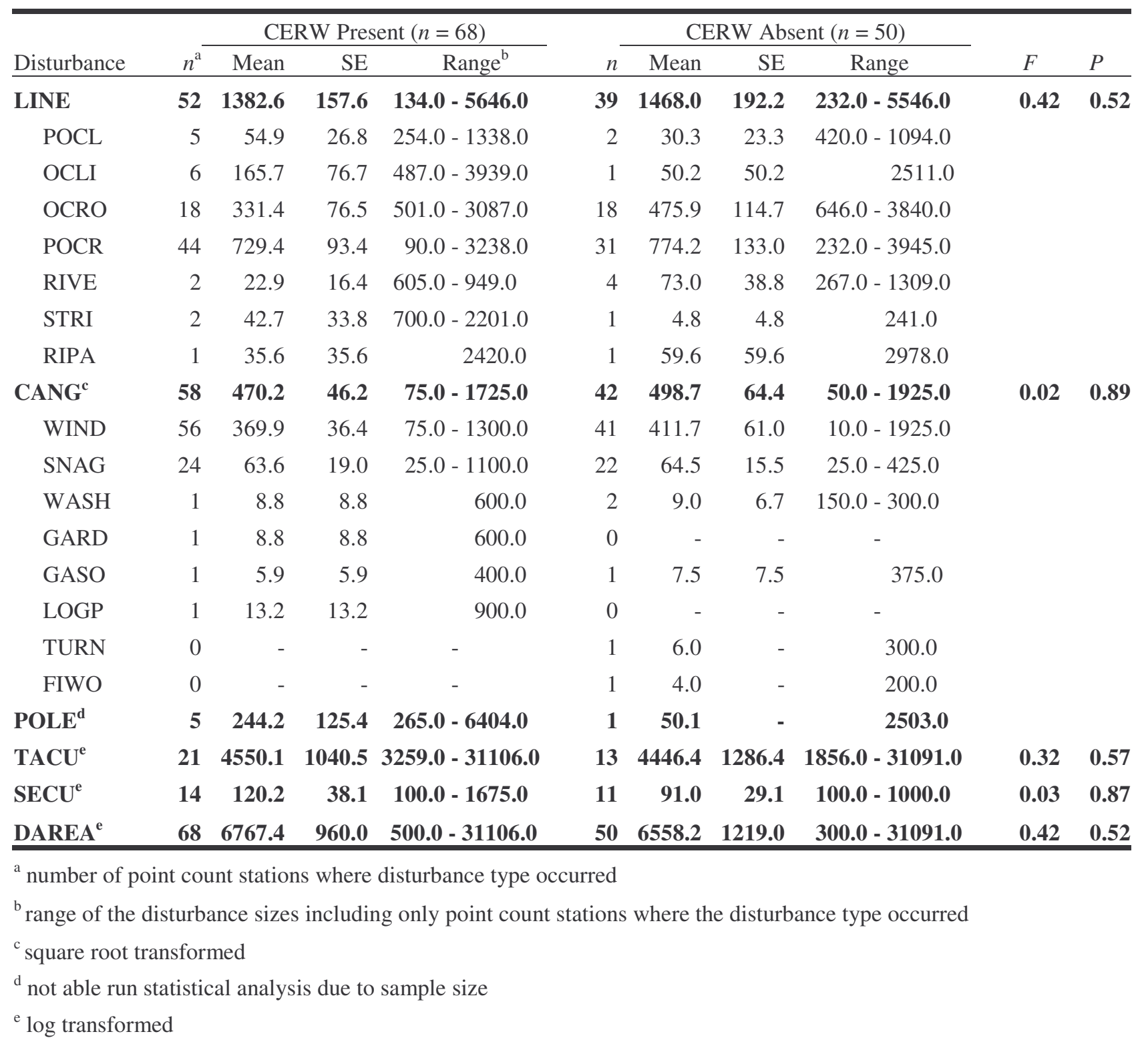


Table 7. Cerulean Warbler (CERW) mean abundance relative to landscape variables calculated within $3 \mathrm{~km}$ radius from each cluster centroid in southwestern West Virginia, 2002.

\begin{tabular}{|c|c|c|c|c|c|c|c|c|c|c|c|}
\hline \multirow[b]{2}{*}{ Variable } & \multicolumn{3}{|c|}{ All Clusters $(n=21)$} & \multicolumn{3}{|c|}{$\begin{array}{l}\text { Clusters with Mean \# } \\
\text { of CERW } \leq 1 \quad(n=13)\end{array}$} & \multicolumn{3}{|c|}{$\begin{array}{l}\text { Clusters with Mean \# } \\
\text { of CERW >1 }(n=8)\end{array}$} & \multirow[b]{2}{*}{$F$} & \multirow[b]{2}{*}{$P$} \\
\hline & Mean & SE & Range & Mean & SE & Range & Mean & SE & Range & & \\
\hline $\mathrm{CDIST}^{\mathrm{a}}$ & 946.1 & 210.9 & $90.0-3050.0$ & 695.5 & 190.1 & $90.0-2035.0$ & 1353.3 & 441.3 & $296.0-3050.0$ & 4.18 & 0.06 \\
\hline \multicolumn{12}{|l|}{ Land Cover } \\
\hline$\%$ DECID & 73.3 & 2.5 & $50.8-93.9$ & 70.7 & 3.2 & $50.8-88.1$ & 77.5 & 3.6 & $62.2-93.9$ & 3.33 & 0.09 \\
\hline$\%$ MIXED $^{\mathrm{b}}$ & 3.6 & 0.6 & $1.4-10.2$ & 2.8 & 0.5 & $1.5-8.7$ & 4.8 & 1.2 & $1.4-10.2$ & 3.19 & 0.09 \\
\hline$\% \mathrm{NON}$ & 23.1 & 2.5 & $3.1-47.6$ & 26.5 & 3.1 & $10.3-47.6$ & 17.6 & 3.5 & $3.1-29.4$ & 2.71 & 0.12 \\
\hline \multicolumn{12}{|l|}{ All Cover } \\
\hline $\mathrm{SDI}^{\mathrm{a}}$ & 1.0 & 0.0 & $1.0-1.1$ & 1.0 & 0.0 & $1.0-1.1$ & 1.0 & 0.0 & $1.0-1.0$ & 3.25 & 0.19 \\
\hline \multicolumn{12}{|l|}{ Forest Cover } \\
\hline$\%$ FOREST $^{\mathrm{b}}$ & 77.5 & 2.6 & $52.4-97.3$ & 73.5 & 3.1 & $52.4-89.7$ & 84.1 & 3.9 & $70.6-97.3$ & 2.62 & 0.12 \\
\hline $\mathrm{MPS}^{\mathrm{b}}$ & 470.2 & 141.9 & $59.4-2738.3$ & 312.0 & 98.5 & $59.4-1261.3$ & 727.5 & 329.7 & $90.3-2738.3$ & 0.51 & 0.49 \\
\hline $\mathrm{AWMSI}^{\mathrm{b}}$ & 3.6 & 0.2 & $2.5-7.4$ & 3.8 & 0.3 & $2.5-7.4$ & 3.3 & 0.2 & $2.7-4.5$ & 0.00 & 0.95 \\
\hline $\mathrm{ED}^{\mathrm{b}}$ & 22.2 & 1.8 & $8.1-47.3$ & 25.0 & 2.4 & $14.7-47.3$ & 17.6 & 2.2 & $8.1-28.8$ & 0.81 & 0.38 \\
\hline TCA & 1646.5 & 126.9 & $305.7-2500.0$ & 1649.4 & 158.4 & $305.7-2286.7$ & 1641.9 & 225.3 & $873.5-2500.1$ & 1.20 & 0.29 \\
\hline MCA & 322.6 & 48.6 & $34.0-833.3$ & 236.1 & 46.3 & $34.0-571.7$ & 463.2 & 85.0 & $153.4-833.3$ & 0.73 & 0.41 \\
\hline $\mathrm{CAD}^{\mathrm{b}}$ & 0.3 & 0.1 & $0.1-1.0$ & 0.4 & 0.1 & $0.1-1.0$ & 0.2 & 0.0 & $0.1-0.4$ & 0.23 & 0.64 \\
\hline
\end{tabular}

${ }^{a}$ power transformed

${ }^{\mathrm{b}} \log$ transformed 
Table 8. Best 5 models relating Cerulean Warbler presence/absence relative to microhabitat variables using logistic regression.

\begin{tabular}{llrr}
\hline Model & AIC $_{\text {C }}$ & Weight \\
\hline ASPECTCO+ $^{a}$ & SAPLINGS- SPOSITION+ & 152.850 & 0.098 \\
ASPECTCO+ & SPOSITION+ & 154.029 & 0.054 \\
ASPECTCO+ & TREES- SPOSITION+ & 154.103 & 0.052 \\
ASPECTCO+ & SNAG_4+ & 154.480 & 0.043 \\
ASPECTCO+ SNAG_4+ SAPLINGS- & 154.802 & 0.037 \\
\hline
\end{tabular}

${ }^{\mathrm{a}}+=$ positive relationship; - = negative relationship

Table 9. Best 5 models relating Cerulean Warbler abundance relative to microhabitat variables using poisson regression.

\begin{tabular}{lrr}
\hline Model & AIC $_{\text {C }}$ & Weight \\
\hline ASPECTCO+ ${ }^{a}$ SNAG_4+ DAREA+ & 219.761 & 0.184 \\
ASPECTCO+ SNAG_4+ & 220.180 & 0.149 \\
ASPECTCO+ SNAG_4+ SPOSITION+ & 220.791 & 0.110 \\
ASPECTCO+ DIST+ SNAG_4+ & 220.837 & 0.107 \\
ASPECTCO+ SNAG_4+ SAPLINGS- & 221.261 & 0.087 \\
\hline
\end{tabular}

${ }^{\mathrm{a}}+=$ positive relationship; - = negative relationship

Table 10. Best 5 models relating Cerulean Warbler mean abundance relative to landscape variables using linear regression.

\begin{tabular}{lrr}
\hline Model & $\mathrm{AIC}_{\mathrm{C}}$ & Weight \\
\hline$\% \mathrm{MIX}+{ }^{\mathrm{a}}$ ED- & -25.197 & 0.124 \\
$\% \mathrm{MIX}+\% \mathrm{DEC}+\mathrm{ED}-$ & -24.848 & 0.105 \\
$\% \mathrm{MIX}+\% \mathrm{DEC}+$ & -24.790 & 0.102 \\
$\mathrm{ED}-$ & -24.515 & 0.088 \\
$\% \mathrm{MIX}+$ ED- CDIST+ & -23.734 & 0.060 \\
\hline
\end{tabular}

${ }^{\mathrm{a}}+=$ positive relationship; - = negative relationship 


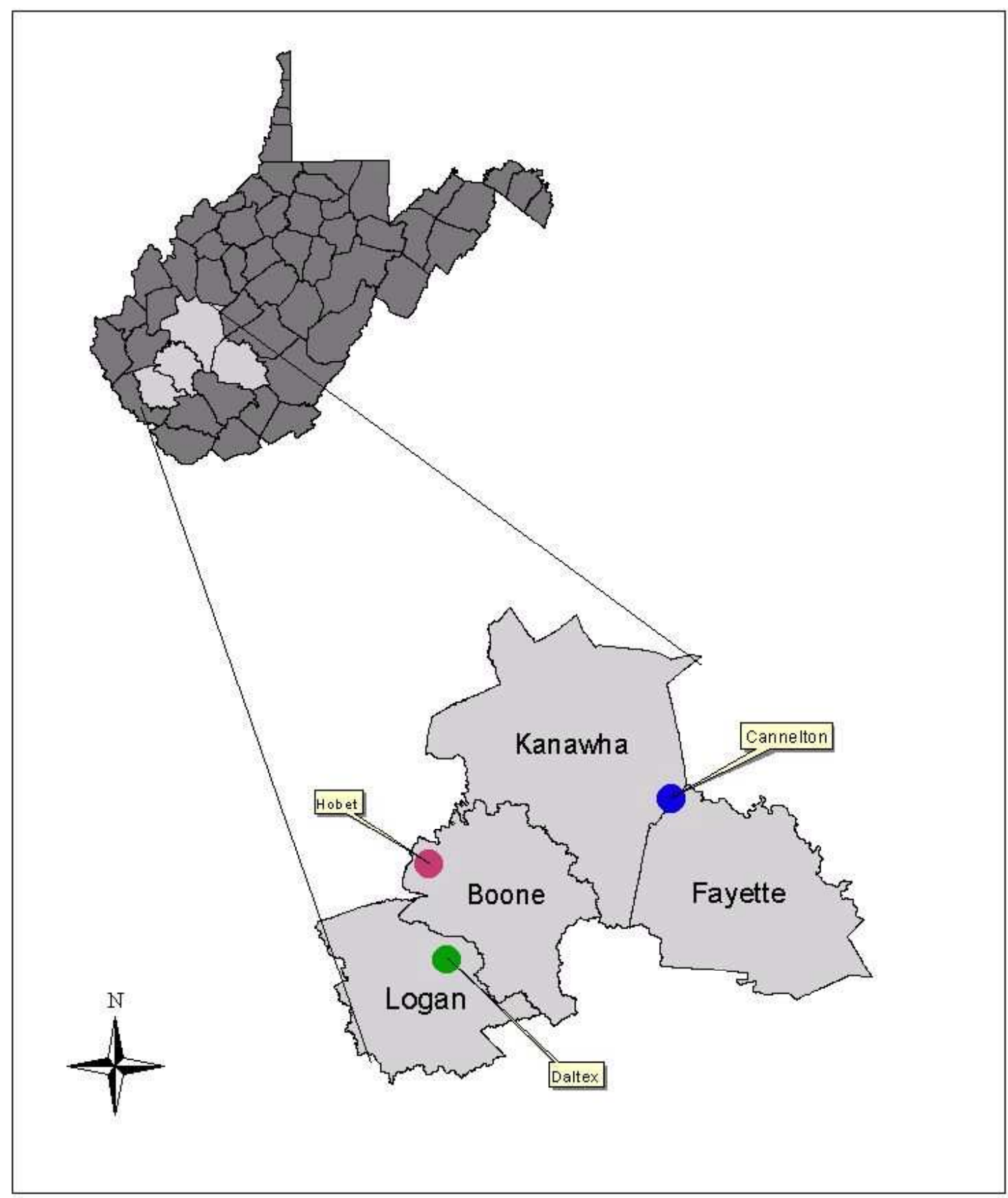

Figure 1. Mountaintop mining/valley fill study sites in southwestern West Virginia, 2002. 


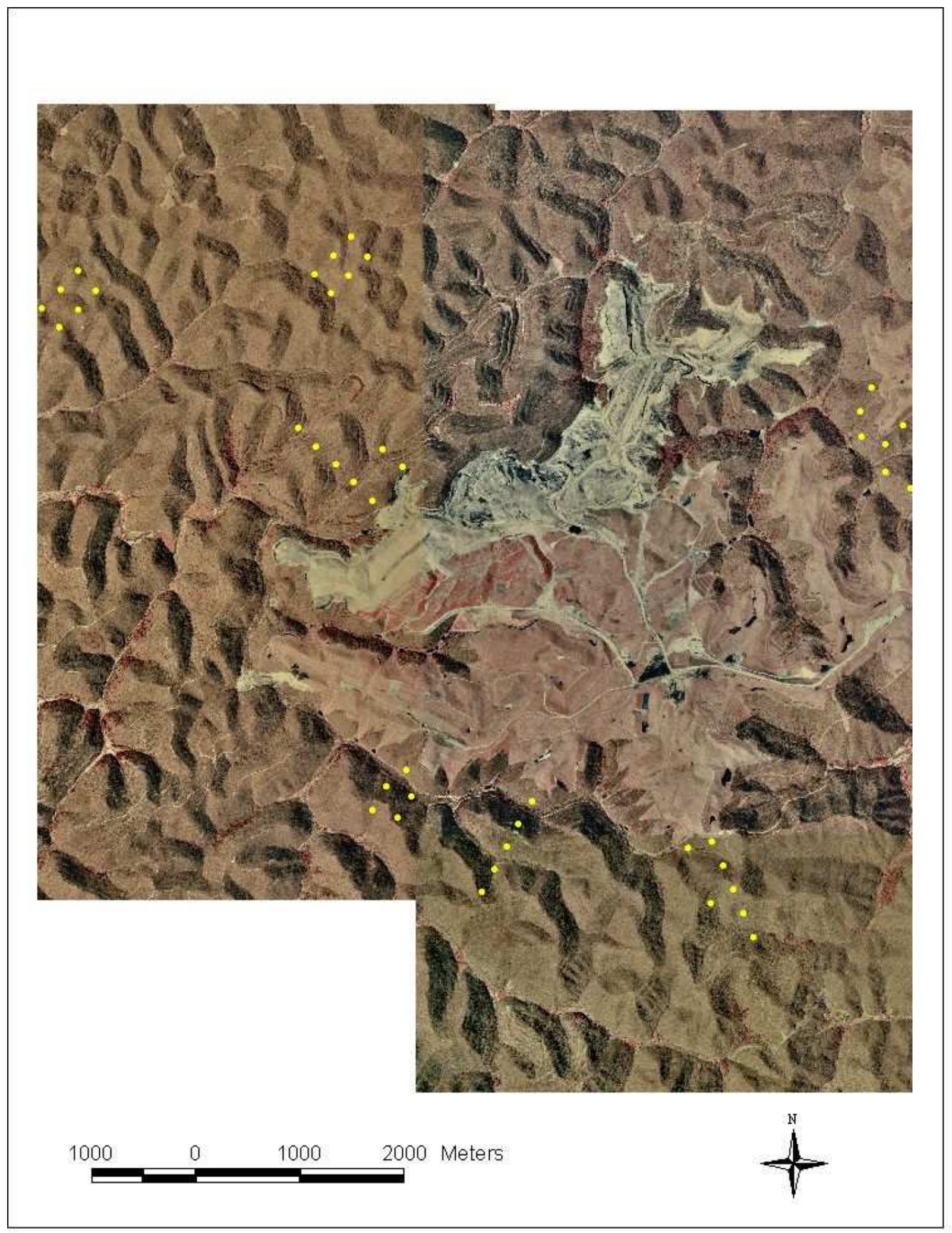

Figure 2. Point count stations in forested habitat at mountaintop mining/valley fill site Hobet 21 in southwestern West Virginia, 2002. 


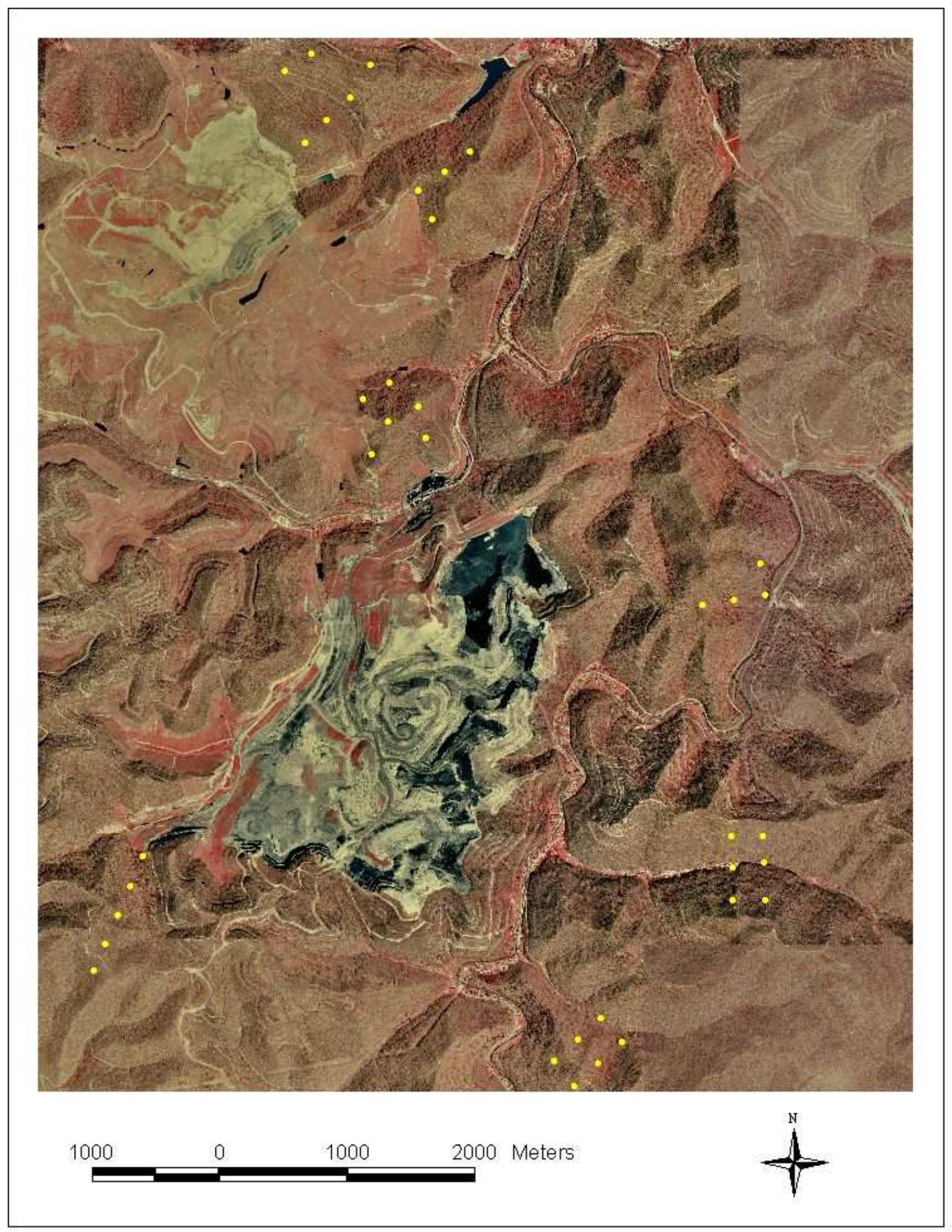

Figure 3. Point count stations in forested habitat at mountaintop mining/valley fill site Daltex in southwestern West Virginia, 2002. 


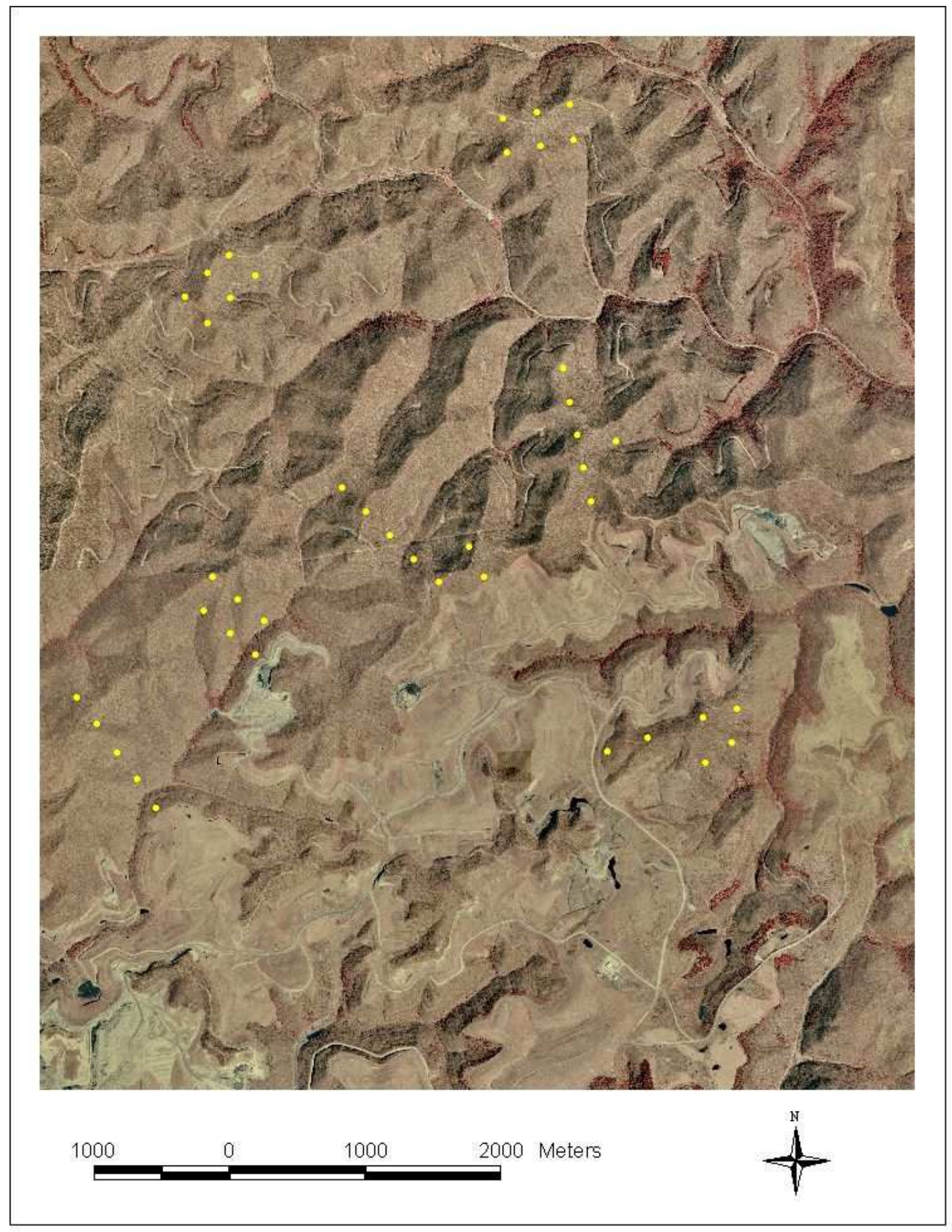

Figure 4. Point count stations in forested habitat at mountaintop mining/valley fill site Cannelton in southwestern West Virginia, 2002. 


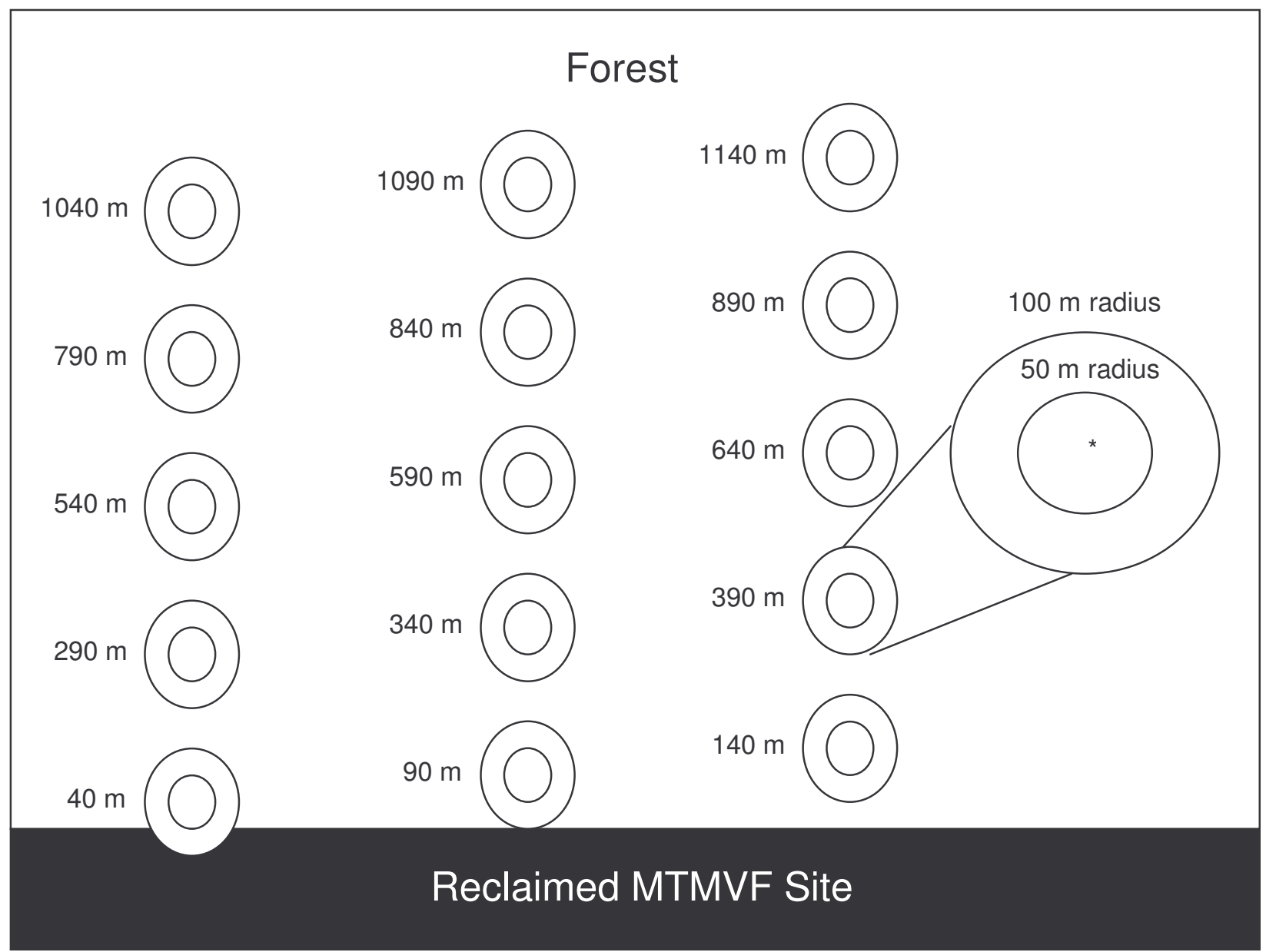

Figure 5. Point count station location and transect layout relative to distance from reclaimed mountaintop mining/valley fill (MTMVF) sites in southwestern West Virginia, 2002. 


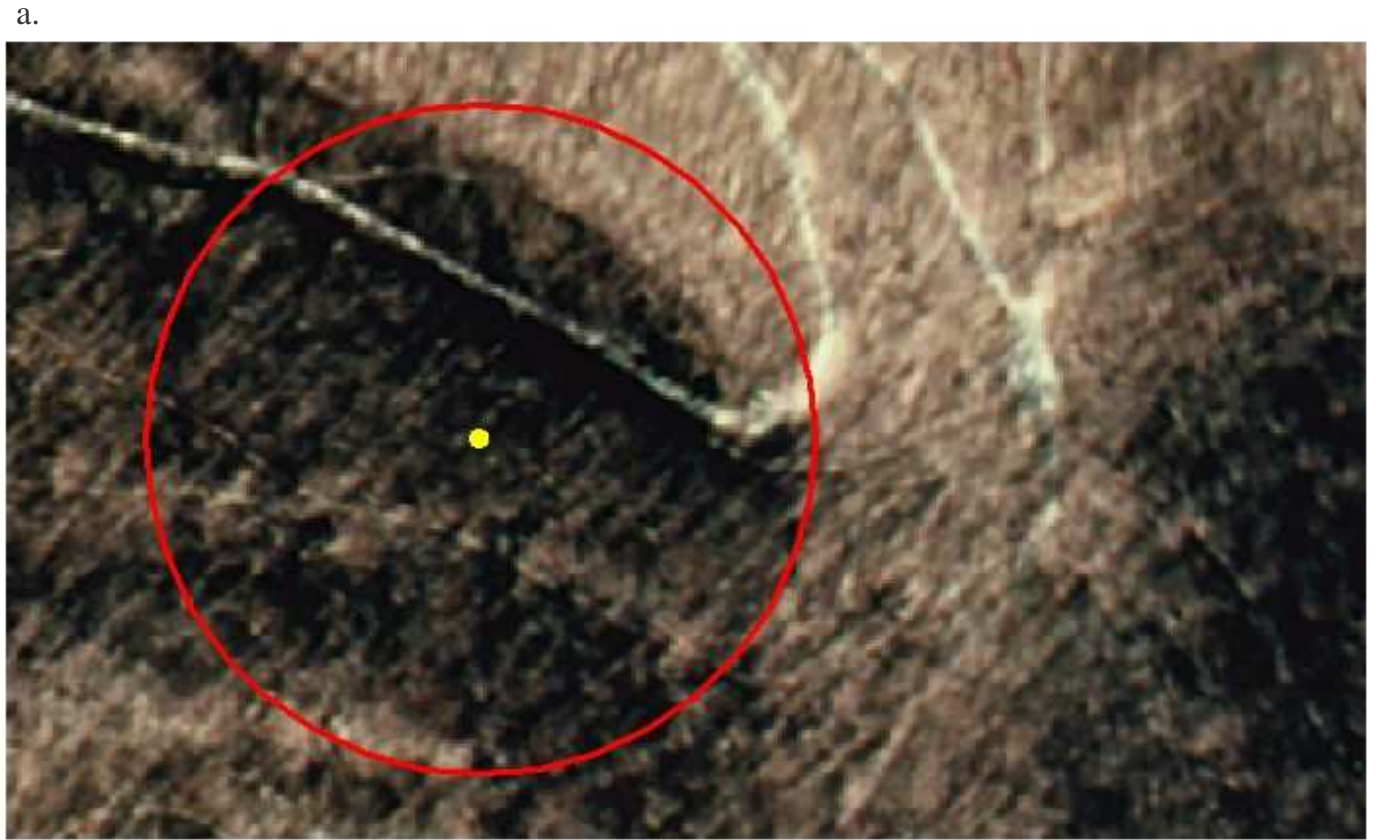

b.

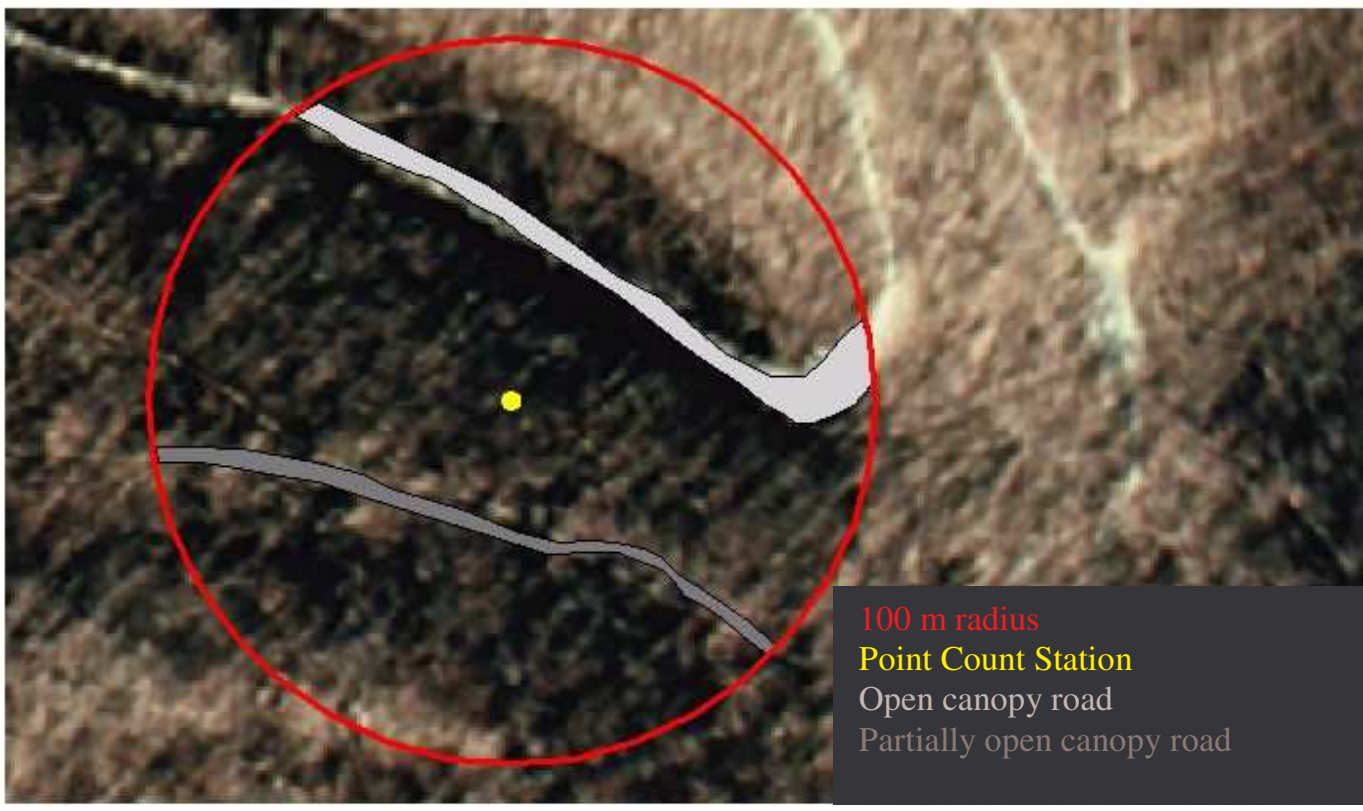

70

0

70

140 Meters

Figure 6. Linear disturbances within $100 \mathrm{~m}$ radius of each point count station in southwestern West Virginia, 2002. Before digitizing (a) and after digitizing (b). 


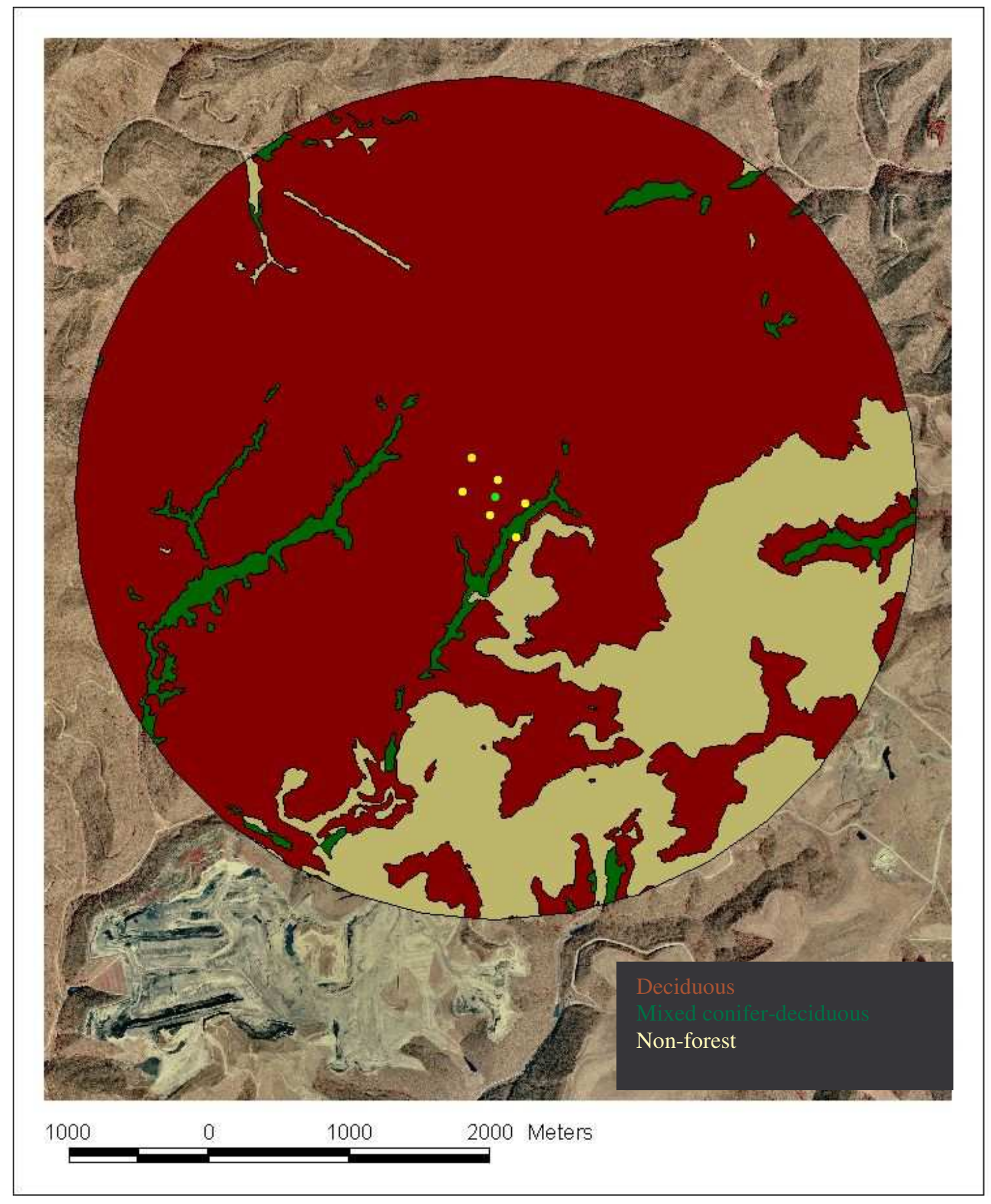

Figure 7. Aerial photograph digitized into 3 land use/land cover categories within a $3 \mathrm{~km}$ buffer from a cluster centroid in a mountaintop mining/valley landscape in southwestern West Virginia, 2002. 


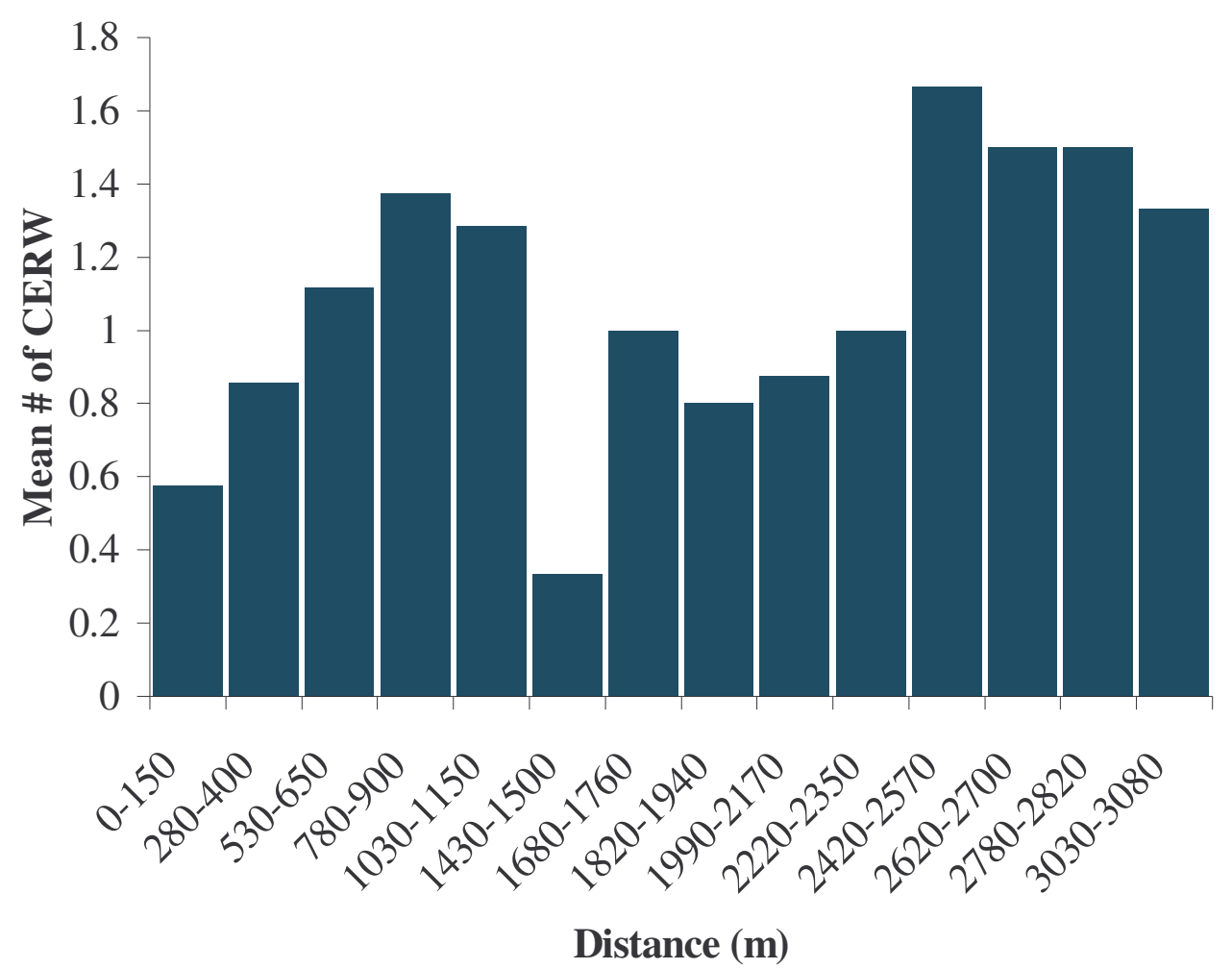

Figure 8. Cerulean Warbler (CERW) abundance relative to all distances $(\mathrm{n}=122)$ from reclaimed mine edge in southwestern West Virginia during May - July 2002. Distance categories were created and mean abundances were calculated to simplify the figure.

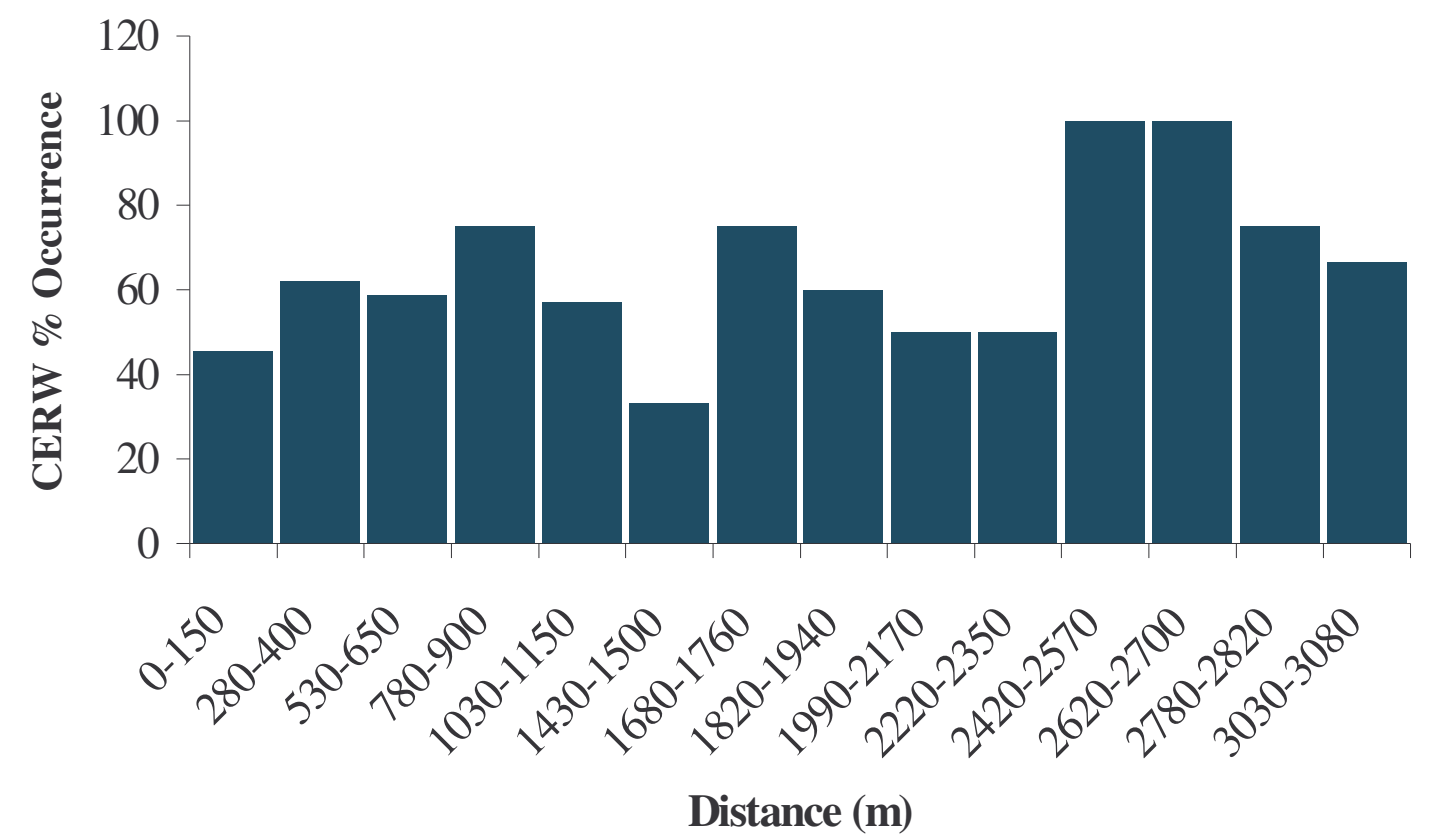

Figure 9. Cerulean Warbler (CERW) percent occurrence (percent of points with CERW present) relative to distance categories in southwestern West Virginia, 2002. 


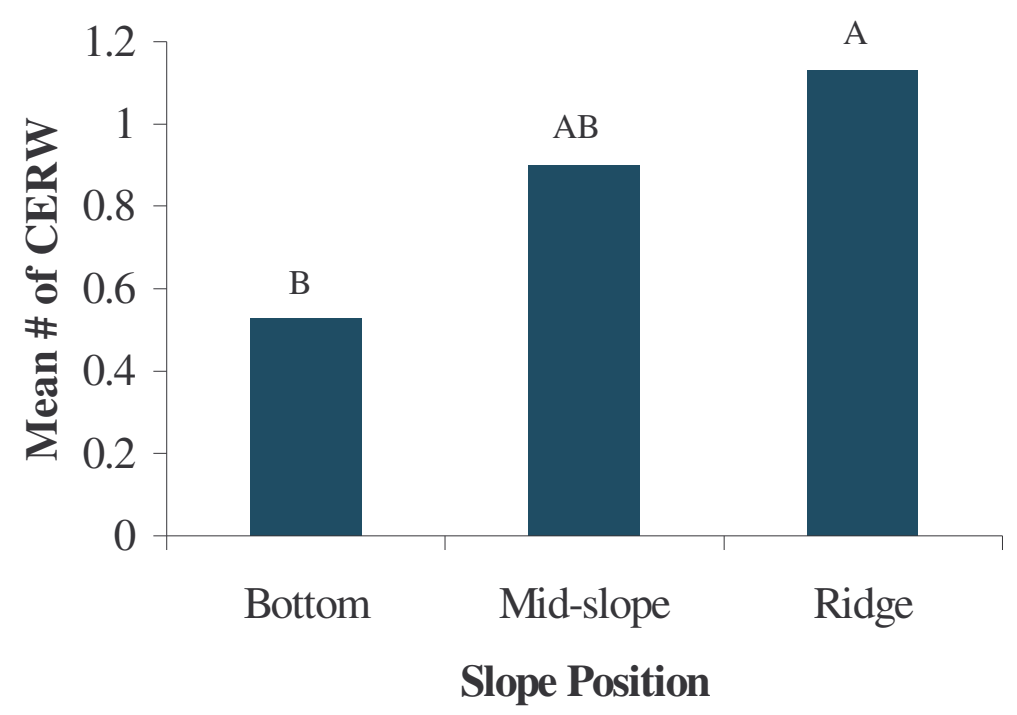

Figure 10. Cerulean Warbler (CERW) mean abundance relative to slope position in southwestern West Virginia during May - July 2002. Like letters indicate no significant difference.

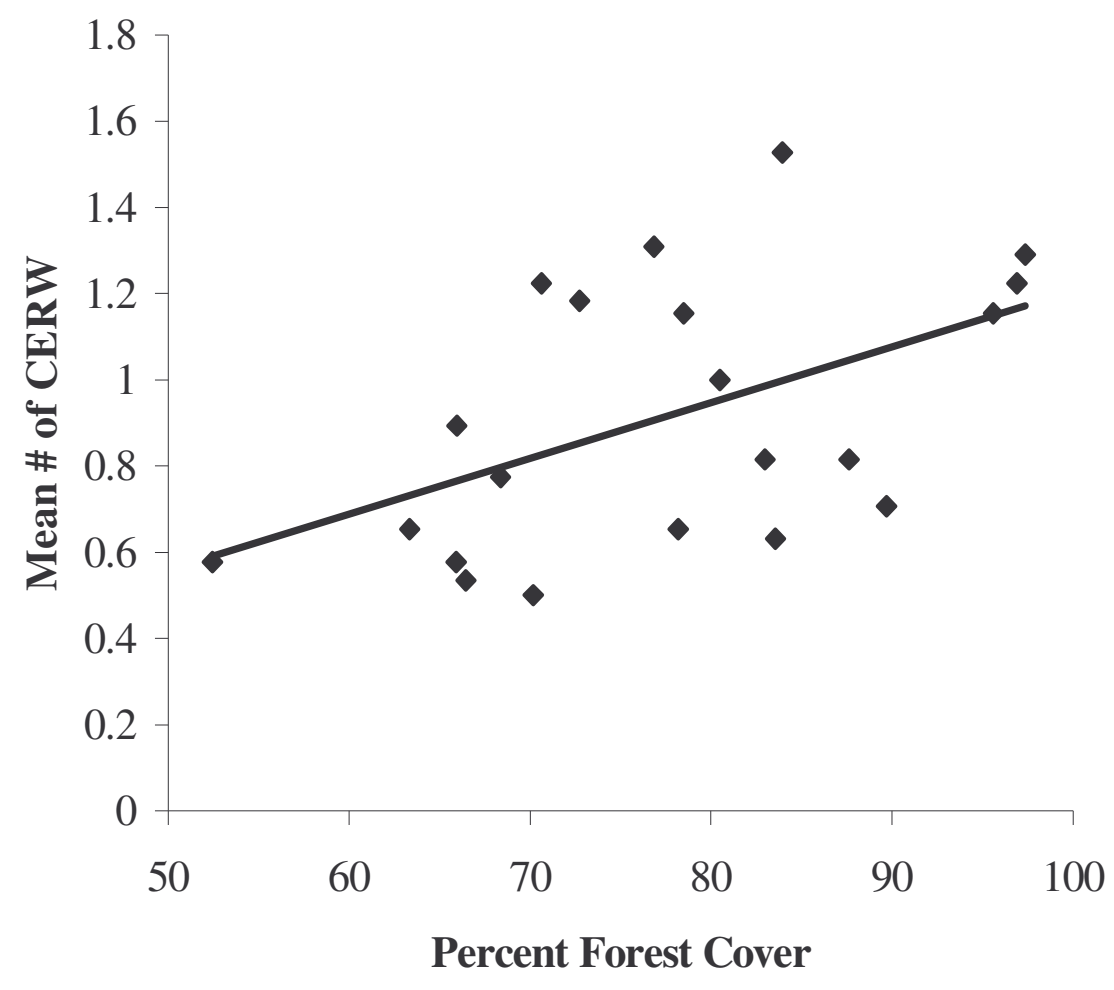

Figure 11. Cerulean Warbler (CERW) mean abundance relative to percent forest cover $\left(R^{2}=0.52, F=4.52, P=0.05\right)$ in southwestern West Virginia during May - July 2002. Forest cover is the combination of deciduous cover and mixed conifer-deciduous. 


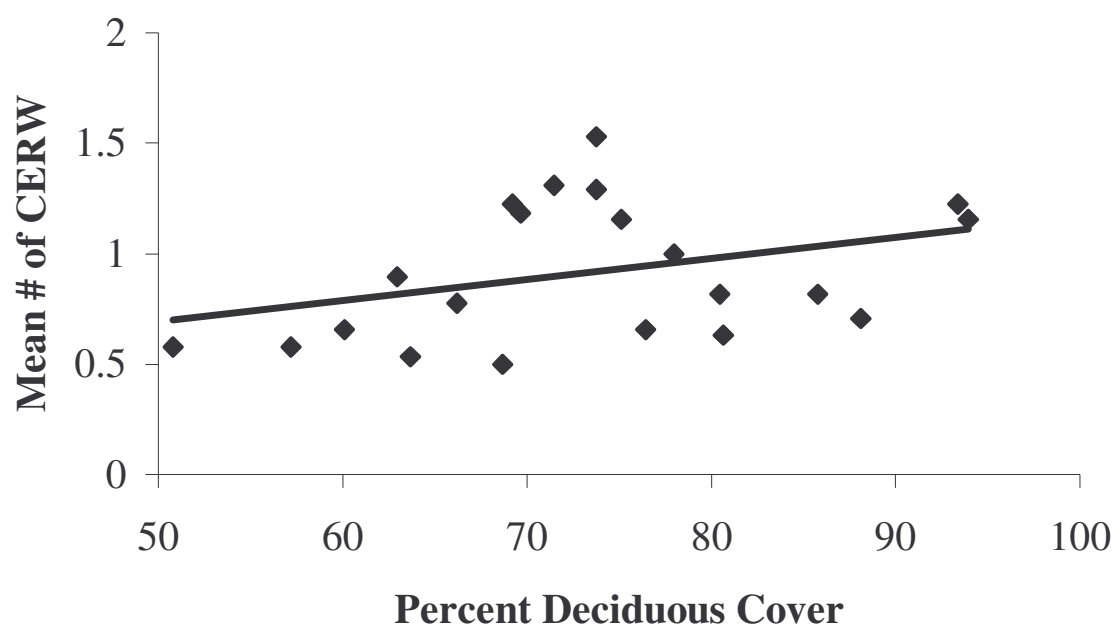

Figure 12. Cerulean Warbler (CERW) mean abundance relative to percent deciduous forest cover $\left(R^{2}=0.51, F=4.19, P=0.06\right)$ in southwestern West Virginia during May - July 2002.

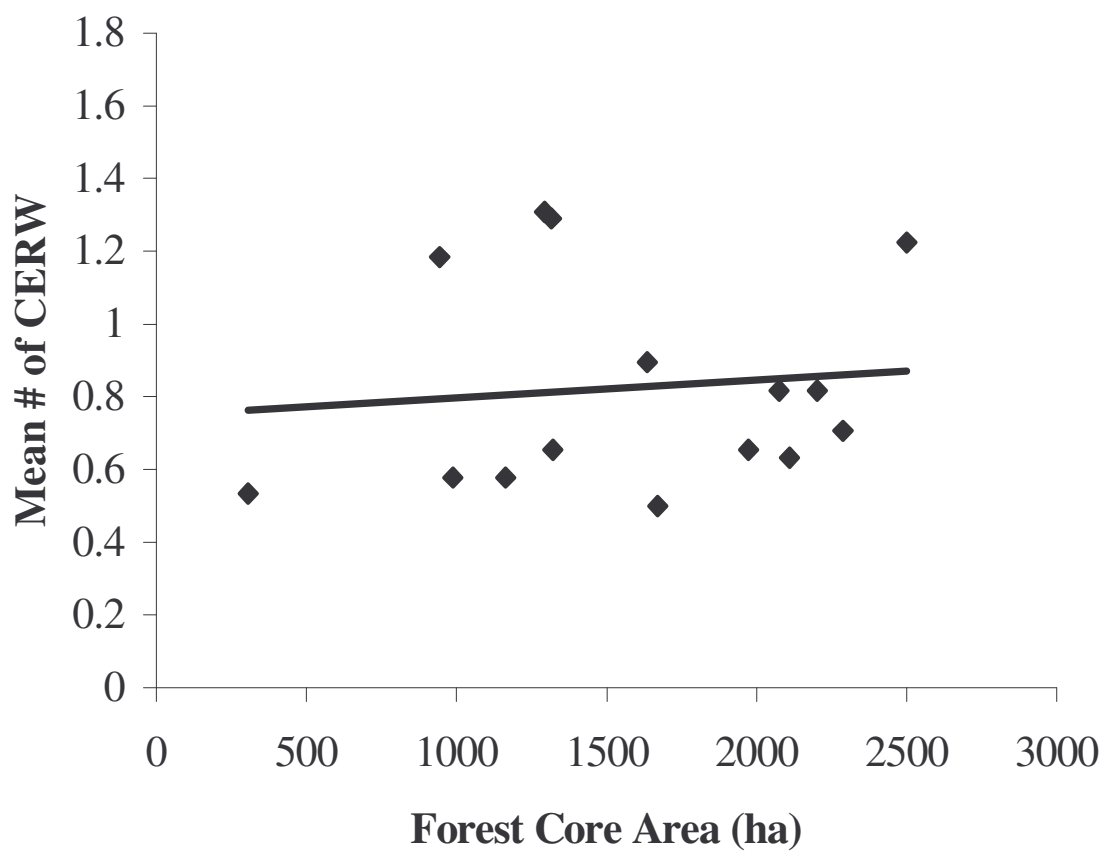

Figure 13. Cerulean Warbler (CERW) mean abundance relative to forest core area $\left(R^{2}=0.52\right.$, $F=4.59, P=0.05$ ) in southwestern West Virginia during May - July 2002. 


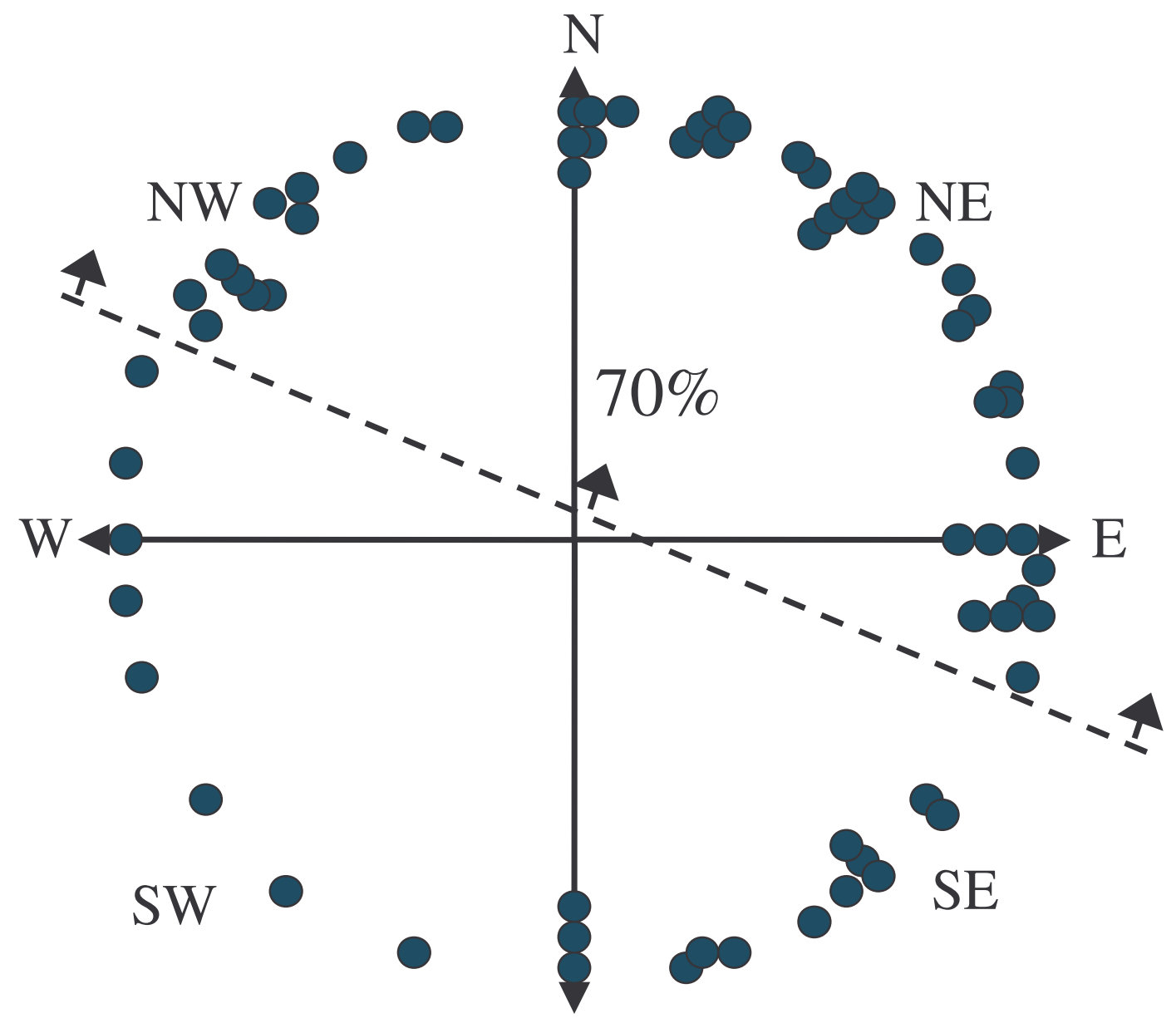

Figure 14. Aspects of point count stations where Cerulean Warblers were present $(n=69)$ in southwestern West Virginia during May - July 2002. Seventy percent of the point count stations are above the dashed line ranging from northwest to east facing slopes. 